\title{
Вклад академика Владимира Филимоновича Дорофеева в развитие сельскохозяйственной и биологической наук
}

\author{
Н.Н. Чикида
}

Аннотация: В августе 2019 г. исполнилось 100 лет со дня рождения Владимира Филимоновича Дорофеева - тритиколога, видного ученого в области ресурсоведения, крупного организатора науки. В статье описаны его биография и основные этапы научной деятельности. В.Ф. Дорофеев начал работать в сети ВИР в 1955 г. сначала начальником базовой станции в Дербенте (Дагестан), затем, с 1960 г., - старшим научным сотрудником отдела зерновых культур. В 1965 г. он был назначен заведующим отделом пшениц, с 1979 по 1987 г. был директором Всесоюзного НИИ растениеводства (ВИР). В 1971 г. ему была присуждена ученая степень доктора наук, издана его монография «Пшеница Закавказья». В.Ф. Дорофеев внес большой вклад в пополнение мировой коллекции ВИР. Он принял участие в 23 экспедициях по сбору растительных ресурсов, в том числе по Закавказью и Северному Кавказу, а также во многих зарубежных странах. В.Ф. Дорофеев уделил большое внимание новой искусственной культуре тритикале. Им было инициировано всестороннее изучение собранного генофонда в эколого-географической экспериментальной сети ВИР и в других научно-исследовательских институтах, описано много новых таксонов пшеницы. В.Ф. Дорофеев возглавил коллективную работу над монографией «Культурная флора СССР, Т. 1. Пшеница», в которой он был также одним из авторов. Большим вкладом в теорию и практику селекции стала книга «Пшеницы мира», написанная В.Ф. Дорофеевым с сотрудниками. Ключевые слова: пшеницы; Triticale; систематика; мировая коллекция; ВИР; В.Ф. Дорофеев.

Благодарности: Работа выполнена в рамках государственного задания ВИР (бюджетный проект № 0662-2019-0006). Автор выражает искреннюю благодарность сотрудникам отдела гербария ВИР (г. Санкт-Петербург) к.б.н. И.Г. Чухиной и Л.В. Багмет за оказанную методическую помощь при работе с гербарным материалом, представленным в статье. Считаем своим приятным долгом поблагодарить за помощь при подготовке статьи к.с.-Х.н. Е.В. Зуева (ВИР).

Для цитирования: Чикида Н.Н. Вклад академика Владимира Филимоновича Дорофеева в развитие сельскохозяйственной и биологической наук. Письма в Вавиловский журнал генетики и селекции. 2020;6(1):18-36. DOI 10.18699/Letters2020-6-04

\section{Contribution of academician Vladimir Filimonovich Dorofeev to the development of agricultural and biological sciences}

\author{
N.N. Chikida $\bowtie$
}

\begin{abstract}
In August 2019, the 100th anniversary of the birth of triticologist, a prominent scientist in the field of cultivated plant resources, a organizer of science Vladimir F. Dorofeev was celebrated. An article describes the biography and the main stages of his scientific activity. V.F. Dorofeev started working in the VIR in 1955, first as the head of an Experimental station in Derbent (Dagestan), then in 1960 as a senior researcher at the Department of cereal crops. In 1965 he was promoted head of Wheat department, and from 1979 to 1987 he was director of the VIR. In 1971 V.F. Dorofeev was granted a Doctor sci. degree (Agric.) and at the same times his monograph "Wheat of the Transcaucasus" came out of print. V.F. Dorofeev contributed much to the replenishment of the world collection of Vavilov Institute. He took part in 23 exploration missions, including Transcaucasus and the North Caucasus regions and many foreign countries. He also paid a great attention to the new synthetic crop - Triticale. He initiated the comprehensive study of the collected gene pool in the ecologo-geographical experimental net of VIR and in other research institutions. He described many new botanical varieties of different wheat species. This work helped V.F. Dorofeev to head a collective work on the monograph "Cultivated Flora USSR. Vol. 1. Wheat" and to be one of its authors. One of the most deserving V.F. Dorofeev's activities was strengthening and extension of relations of VIR with breeding centers of the country. A great contribution to the theory and practice of breeding was the book "Wheats of the World" written by V.F. Dorofeev and co-workers of his department.
\end{abstract}

Key words: wheat; Triticale; taxonomy; world VIR collection; Vavilov Institute of Plant Industry; V.F. Doroveev.

For citation: Chikida N.N. Contribution of academician Vladimir Filimonovich Dorofeev to the development of agricultural and biological sciences. Pisma v Vavilovskii Zhurnal Genetiki i Selektsii = Letters to Vavilov Journal of Genetics and Breeding. 2020;6(1):18-36. DOI 10.18699/Letters2020-6-04 (in Russian) 
Владимир Филимонович Дорофеев родился 14 августа 1919 г. в селе Вышне-Ольшанское Должанского района Орловской области в крестьянской семье Дорофеевых Филимона Тимофеевича и Софьи Михайловны. В 1936 г. с отличием окончил Вышне-Ольшанскую неполную среднюю школу. В 1939 г., после окончания Ливенского педагогического училища, В.Ф. Дорофеев работал учителем начальной школы в пос. Жупаново Камчатской области. В декабре 1939 г. он был призван в ряды Советской Армии и направлен в школу молодых командиров отдельного батальона связи Петропавловск-Камчатского военного округа. В апреле 1941 г. был послан на учебу в Ульяновское военное училище связи им. Серго Орджоникидзе.

В.Ф. Дорофееву довелось воевать под Сталинградом и на Курской дуге. В боях за железнодорожную станцию Прохоровка он получил тяжелую контузию, но снова вернулся на фронт. Принимал участие в освобождении Киева, Западной Украины, Будапешта, Праги. Закончил военную службу в звании гвардии капитана. За боевые заслуги В.Ф. Дорофеев был награжден орденом Отечественной войны I степени, двумя орденами Красной Звезды, медалями «За отвагу», «За освобождение Киева», «За победу над Германией в Великой Отечественной войне 1941-1945 гг.» и др.

После демобилизации из армии, в 1947 г., Владимир Филимонович поступил на отделение декоративного садоводства Московской сельскохозяйственной академии им. К.А. Тимирязева (ТСХА, г. Москва), обучение окончил с отличием. Еще будучи студентом, он приобщился к научной работе. Этот период имел важное значение в становлении молодого исследователя. В 1952-1955 гг. под руководством известного советского ботаника академика ВАСХНИЛ П.М. Жуковского (Гончаров, 2013) В.Ф. Дорофеев выполнил аспирантскую работу на тему: «Морфолого-анатомическое исследование вегетативных органов культурных представителей рода Brassica L.» (Дорофеев, 1955, 1957).

Для экспериментов было выбрано пять возделываемых видов одного рода, у которых пищевую или кормовую ценность имеют разные органы: корень и подсемядольное колено - турнепс, репа, брюква; почка - листовая капуста; стебель - капуста кольраби. На этих объектах был проведен детальный анализ морфологических и анатомических изменений в тканях вегетативных и репродуктивных органов в ходе онтогенеза (интервал между наблюдениями был от 5 до 10 дней). В результате исследований В.Ф. Дорофеев показал сходство начальных фаз онтогенеза всех изученных культур: ход прорастания семян, дифференциация осевых органов, морфолого-анатомические особенности в строении проростков и др. Их морфологические отличия в этот период ограничивались лишь размером, окраской семядолей и верхней части колеоптиле. В работе описана последовательность основных структурных изменений, имеющих место при формировании корне- и стеблеплодов, ведущих к их разрастанию. В опытах с контрастными фотопериодами было обнаружено влияние внешней среды на темпы развития (прохождения онтогенеза) двулетних растений.

Несмотря на кажущуюся сугубо теоретическую направленность аспирантской работы, В.Ф. Дорофеев сумел найти пути практического использования полученных ре-

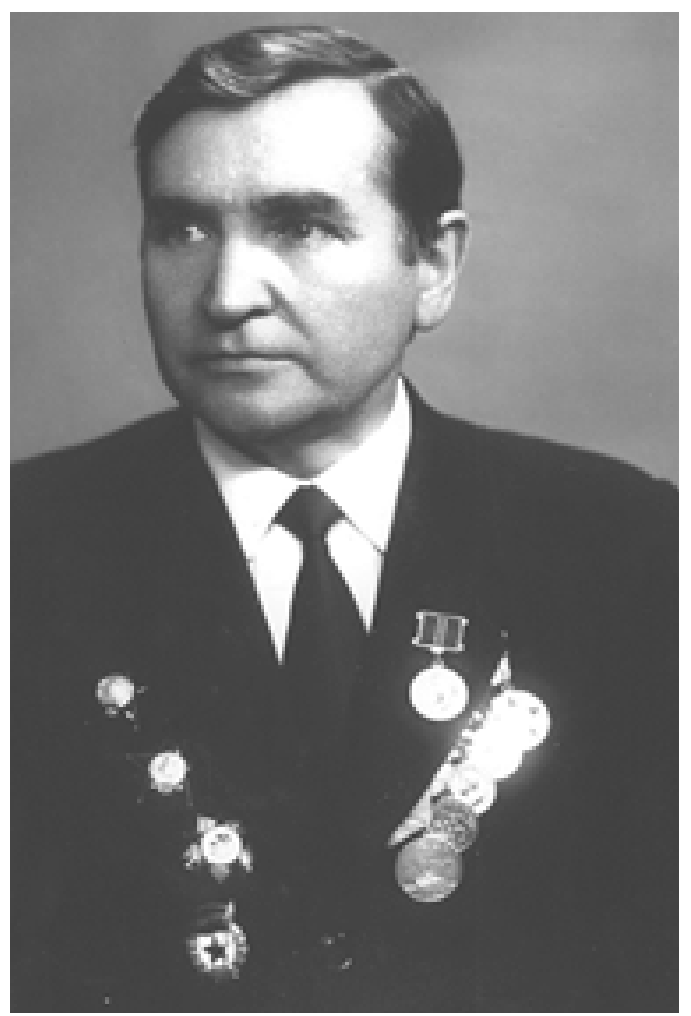

зультатов: им был сделан ряд предложений для совершенствования агротехники изученных представителей рода Brassica L. - уточнены оптимальные сроки проведения подкормок, указано на важность раннего окучивания проростков и сохранения семядолей молодых растений. Поражает число измерений и анатомических анализов, выполненных им: только постоянных препаратов было изготовлено 1500 , диссертация иллюстрирована 228 рисунками и фотографиями. Все это свидетельствует о его завидной работоспособности и большой скрупулезности в научных исследованиях. По-видимому, именно аспирантские годы оказали решающее влияние на формирование творческого почерка Владимира Филимоновича: он любил в работе красивый замысел, точное знание предмета и методов исследования, тщательность исполнения намеченных планов, четкость выводов и стремление к практическому использованию полученных фундаментальных знаний. В стенах Тимирязевской академии он получил еще один бесценный навык - грамотно и лаконично излагать свои мысли. Этому способствовало то, что Владимир Филимонович с аспирантских лет активно участвовал в педагогической работе, пройдя путь от ассистента до доцента кафедры.

После успешной защиты кандидатской диссертации в 1955 г. В.Ф. Дорофеев стал руководителем Дербентского опорного пункта Всесоюзного НИИ растениеводства (ВИР), сменив столичный город на маленький дагестанский поселок. Это событие круто изменило его судьбу и навсегда связало с флагманом отечественной растениеводческой науки - ВИР. На Дербентском опорном пункте (ныне Дагестанская опытная станция ВИР), одном из важнейших мест изучения мировой коллекции пшеницы, он увидел удиви- 

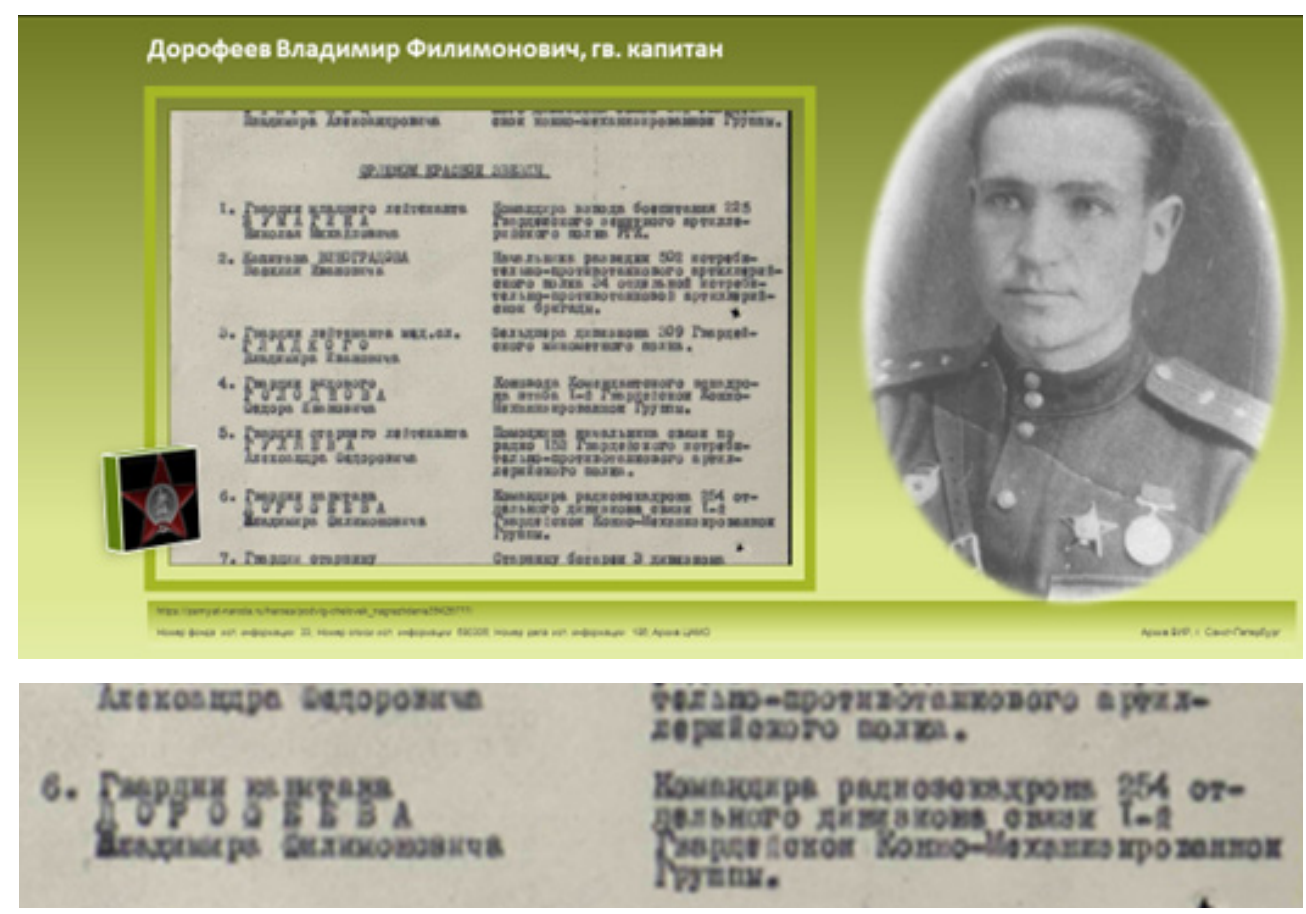

(https://pamyat-naroda.ru/heroes/podvig-chelovek_nagrazhdenie 39426777/

Номер фонда ист. информации 33; номер описи ист. информации 690306; номер дела ист. информации 186; архив ЦАМО; архив ВИР (Санкт-Петербург)

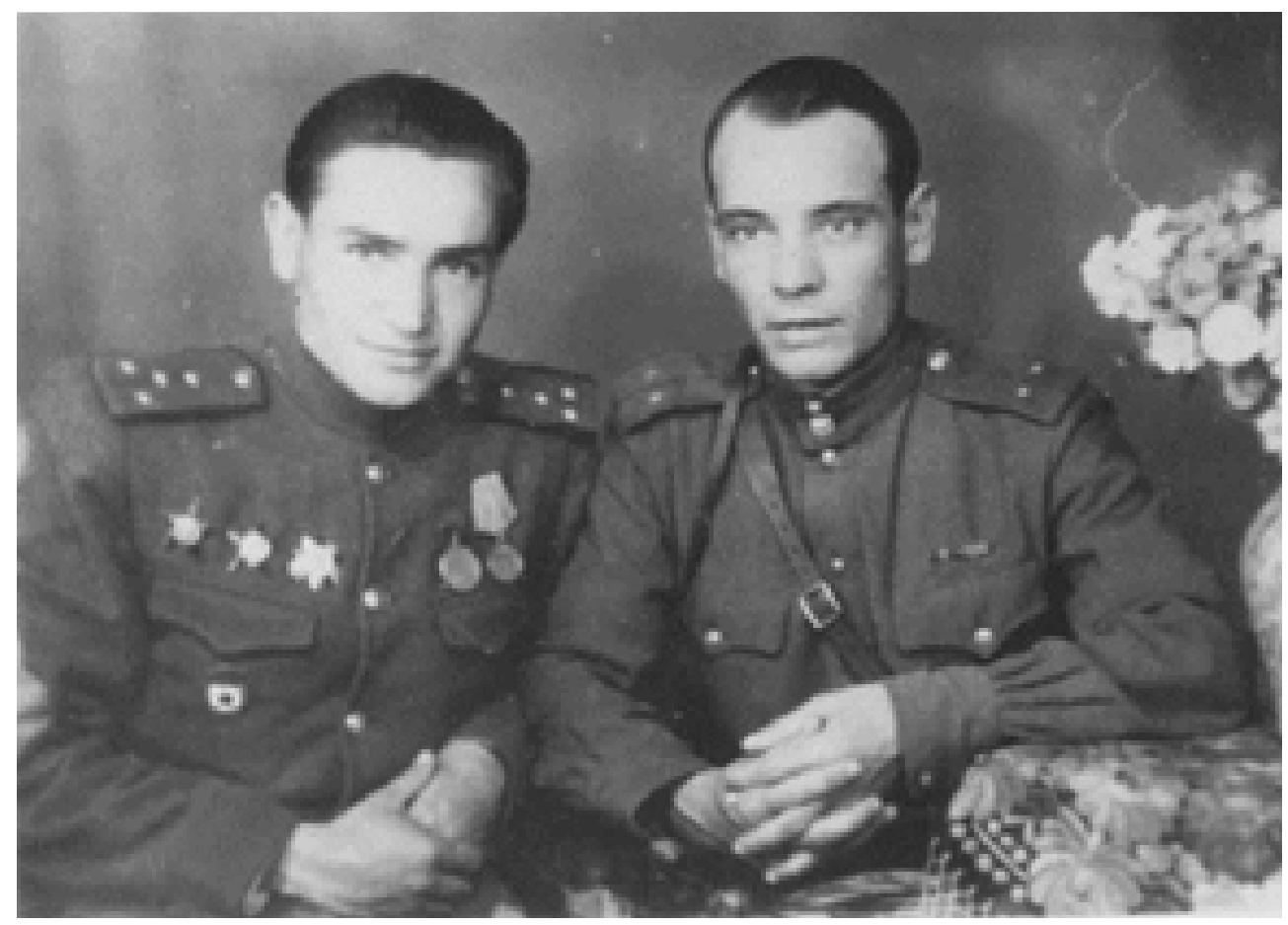

В.Ф. Дорофеев (слева) с фронтовым другом (1944)

V.V. Dorofeev (on the left) with a friend from the war (1944)

тельное разнообразие этой культуры. Здесь же Владимир Филимонович приобрел навыки коллектора растений, обследуя пшеничные поля предгорного и горного Дагестана. Летом 1960 г. по приглашению своего учителя П.М. Жуковского, ставшего директором ВИР, Владимир Филимонович принял участие в конкурсе на замещение вакантной должности старшего научного сотрудника отдела зерновых культур и был зачислен в штат Института. Через пять лет, в 1965 г., он возглавил отдел пшениц Института и руководил им до последних дней своей жизни. Исключительно инте- 


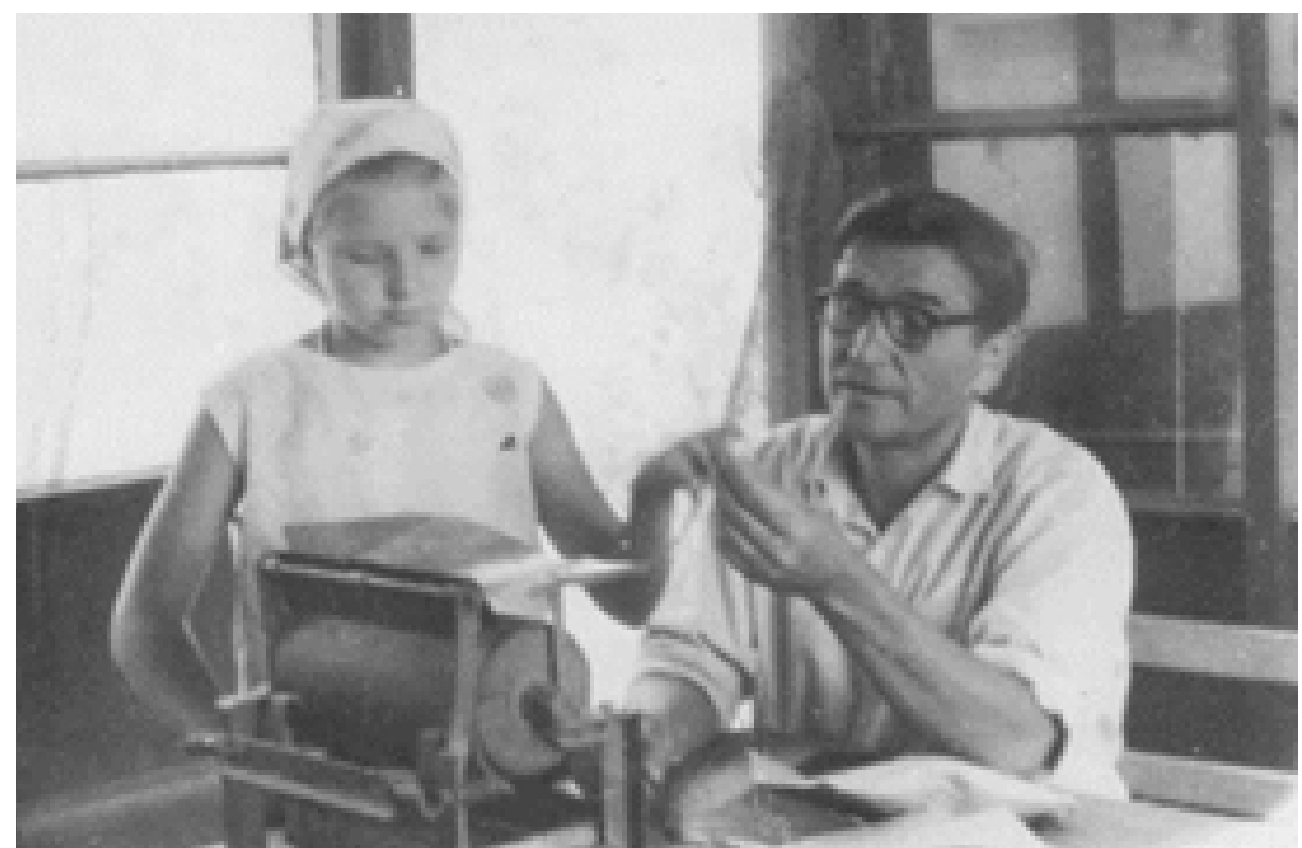

В лаборатории Дербентского опорного пункта с дочерью Леной: идет анализ колоса пшеницы (1962)

Analyzing wheat ears in Derbent laboratory with daughter Lena (1962)

ресная и разнообразная тематика исследований Института, прекрасный коллектив ученых, присутствующий здесь дух регелевских и вавиловских идей, начавшееся в середине 1960-х гг. бурное развитие растениеводческой науки создали прекрасный фон для дальнейшего формирования научного мировоззрения В.Ф. Дорофеева.

До середины прошлого столетия на полях страны господствовали высокорослые пшеницы, исключительно остро стояла проблема борьбы с полеганием хлебов. Владимир Филимонович активно включился в ее решение, используя приобретенные в аспирантуре знания анатома и морфолога. Под его руководством эта работа с самого начала стала многоплановой: на обширном материале из коллекции ВИР изучали имеющееся в мире видовое и внутривидовое разнообразие пшениц по высоте растений, морфологическим, механическим и анатомическим характеристикам корня, стебля и листовых влагалищ (Дорофеев, 1959, 1960, 1962; Дорофеев, Градчанинова, 1971; Мережко, Градчанинова, 1982).

При этом не только констатировались особенности строения того или иного органа растения пшеницы, но и велся целенаправленный поиск связи этих характеристик с устойчивостью к полеганию (Дорофеев, 1962). Последняя работа была посвящена анатомическому строению междоузлий и узлов стебля растений восьми видов пшеницы. Было обращено внимание на важную роль листовых влагалищ в устойчивости растений к полеганию, так как они формируют хорошо развитую механическую ткань и приобретают прочность раньше, чем защищаемые ими участки стебля. Выявлены отличия в анатомическом строении разных частей междоузлий, что важно учитывать при взятии проб для анализа сравниваемых сортообразцов.
Поиск надежного экспресс-метода оценки исходного и селекционного материала на устойчивость к полеганию выявил еще одно дарование Владимира Филимоновича изобретательность. Совместно со специалистами Агрофизического института (г. Ленинград) и Центрального ОКБ ВАСХНИЛ он сконструировал приборы для определения таких показателей, как прочность стебля на излом, его упругость и сила сцепления корней с почвой. Эти приборы широко использовались во многих научно-исследовательских учреждениях и селекцентрах страны (Янченко, 1983).

Важную роль в изучении устойчивости хлебов к полеганию сыграл обстоятельный обзор мировой литературы по этой проблеме, подготовленный В.Ф. Дорофеевым и В.И. Пономаревым (1970). В нем подробно рассмотрены все известные к тому времени факторы, влияющие на устойчивость пшеницы к полеганию, существующие методы изучения этого признака и пути решения данной проблемы с помощью селекции. При этом была особо подчеркнута главенствующая роль рецессивных и доминантных генов $R h t$ (reduced height), контролирующих короткостебельность, в повышении устойчивости пшеницы к полеганию. Четкое осознание этого факта ранее стало переломным моментом в селекции культуры (Borlaug, 1968). ВИР сформировал фонд карликовых и короткостебельных образцов пшеницы (Дорофеев, Сурганова, 1970; Дорофеев и др., 1970, 19736; Дорофеев, 1975), организовал его всестороннее генетическое изучение (Звейнек, 1984; Мережко и др., 1986; Мережко, 1991; Альдеров, 2001; и др.) и использование в селекционных центрах страны, созданных в начале 1970-х гг. (Шумный, Гончаров, 2008). Как следствие этой напряженной работы, вскоре почти во всех регионах СССР появились неполегающие отечественные сорта пшеницы (Лукьяненко, 1969; Беспалова, 2001; Лоскутова, 2002; Чеботарь и др., 2016). 


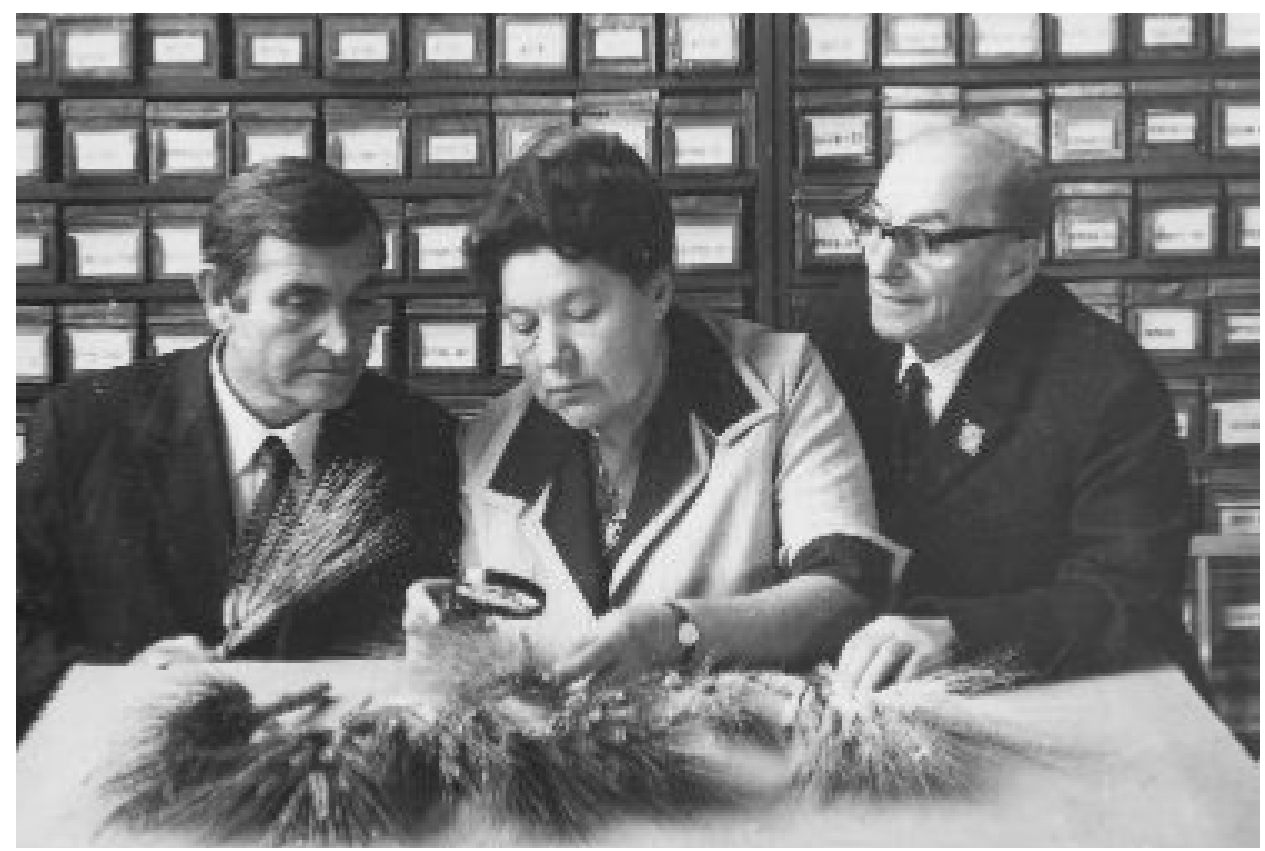

За изучением новых форм пшеницы (1968). Слева направо: В.Ф. Дорофеев, М.И. Руденко, М.М. Якубцинер

Studying on a new varieties of wheat (1968). V.F. Dorofeev (on the left), M.I. Rudenko, M.M. Yakubtsiner

Новый поворот в научной судьбе Владимира Филимоновича Дорофеева опять был связан с П.М. Жуковским. Опытный ботаник посоветовал ему как можно полнее собрать и досконально изучить разнообразие пшениц Закавказья, с учетом новейших данных уточнить их место в эволюции рода Triticum L. и определить потенциал для использования в селекции. Благодаря четко выраженной вертикальной зональности, географическому расположению между двумя морями, Каспийским и Черным, изолированности от проникновения холодных воздушных масс с севера, большому количеству солнечной радиации и другим факторам внешней среды этот регион отличается большим почвенно-климатическим разнообразием и богатейшей растительностью. Судя по археологическим находкам, генофонд пшеницы формировался здесь на протяжении многих тысячелетий - со времен позднего неолита (Менабде, 1948). Закавказье издавна привлекало внимание многих известных ботаников, таких крупных знатоков пшеницы, как Н.И. Вавилов, К.А. Фляксбергер, П.М. Жуковский, Л.Л. Декапрелевич, М.Г. Туманян, И.Д. Мустафаев, Н.Н. Кулешов, В.Л. Менабде, М.М. Якубцинер, Е.А. Столетова, П.А. Гандилян и др. (Соратники..., 2017).

Многочисленные труды этих ученых облегчали стоящую перед В.Ф. Дорофеевым задачу, но и поднимали планку требований к его работе на очень высокий уровень. Для него было очень важно найти свое место в этих исследованиях, чтобы не затеряться в огромном потоке «пшеничной» информации. В этой ситуации Владимир Филимонович принял, пожалуй, наиболее перспективное решение - повторить всеобъемлющее обследование территории Закавказья через несколько десятилетий после первых вировских экспедиций (Щербаков, 1969; Щербаков, Чикова, 1971) и про- вести максимально полную инвентаризацию произрастающих здесь пшениц и эгилопсов на фоне ранее известных и новых данных по эволюции рода Triticum. Он с энтузиазмом начал эту работу, став руководителем постоянно действующей экспедиции ВИР по Закавказью и Северному Кавказу (1961-1984 гг.).

В результате крупномасштабного обследования земледельческих районов Азербайджана, Армении и Грузии экспедиция В.Ф. Дорофеева собрала около 1000 образцов пшеницы и более 200 образцов эгилопса. Всестороннее изучение их в сравнении с материалом довоенных сборов экспедиций ВИР и анализ полученных данных с применением вавиловского дифференциального систематико-географического подхода (Vavilov, 1940) дали очень интересные результаты (Дорофеев, 1966, 1968а, 1969а; Дорофеев, Мигушова, 1966; Дорофеев и др., 1969, 1970а, 6, 1971а, 6, 1972, 1976а). Было подтверждено наличие исключительного разнообразия пшеницы и ее сородичей на территории Закавказья. На одном поле здесь часто произрастают разновидности нескольких видов: Triticum aestivum L., T. durum Desf., T. turgidum L., T. spelta L. и др. В качестве примесей обычны сорно-полевая рожь Secale segetale (Zhuk.) Roshev. и эгилопсы Aegilops cylindrica Host, Ae. triaristata Willd., Ae. biuncialis Vis., Ae. squarrosa L. (син. Ae. tauschii Coss.) и др. На пшеничных полях Закавказья возникают своеобразные естественные питомники гибридизации. Вертикальная зональность, пестрота климата и почв создают здесь предпосылки для спонтанного переопыления видов пшеницы, а также пшеницы с рожью и эгилопсами, что обусловливает появление в посевах сложных по составу популяций. Экспедицией В.Ф. Дорофеева выявлены многочисленные внутривидовые, а также межвидовые гибриды от скрещивания разныхвидов пшениц 


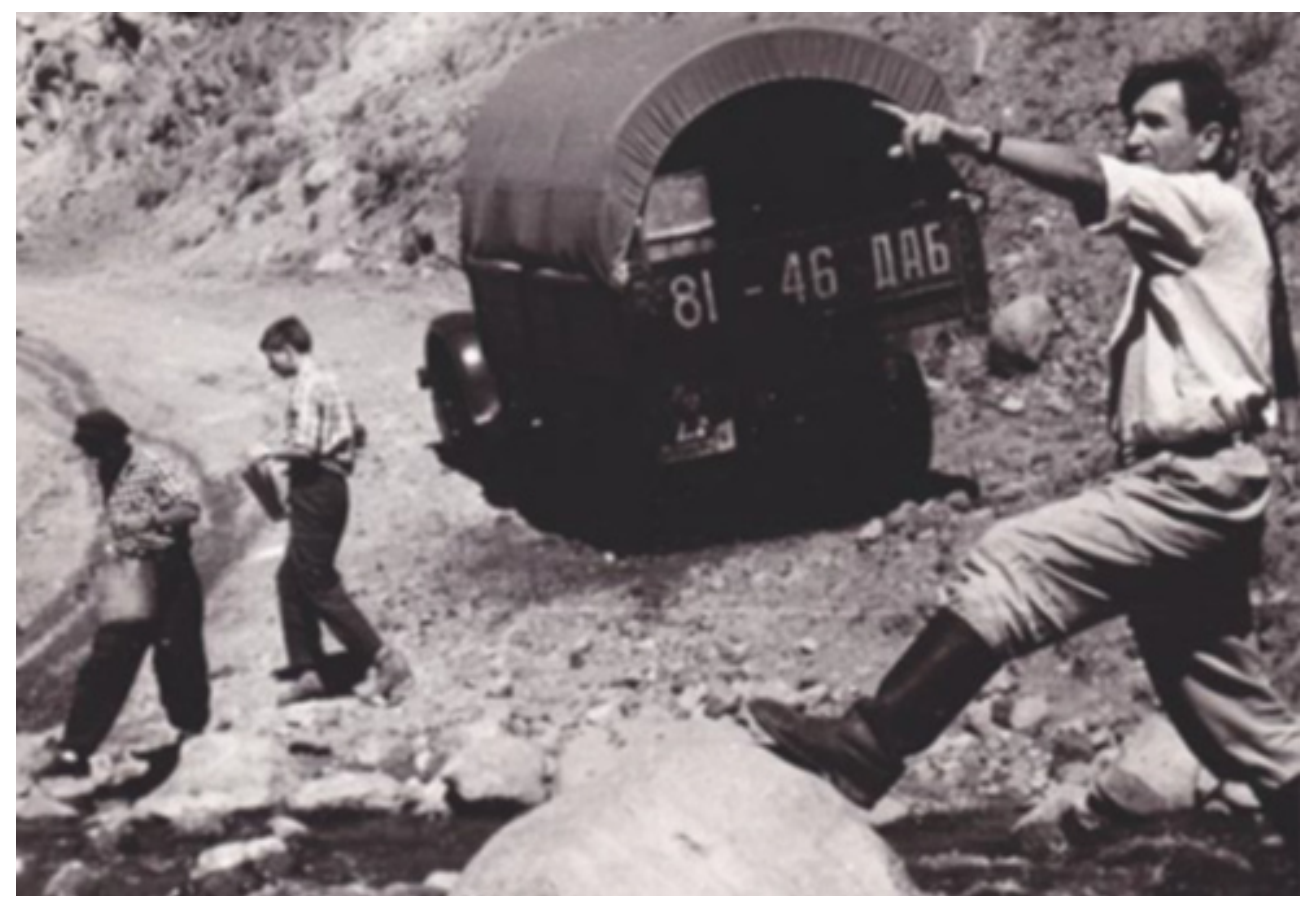

Экспедиция по Закавказью (1961)

Transcaucasia expedition (1961)

(T. durum $\times$ T.turgidum, T. durum $\times$ T. dicoccum (Schrank) Schuebl., T. durum $\times$ T. persicum Vav. (син. T. carthlicum Nevski), T. durum $\times$ T. polonicum L., T. durum $\times$ T. aestivum, T. turgidum $\times$ T. aestivum) и межродовые гибриды (Triticum $\times$ Secale L., Triticum $\times$ Aegilops L.). Донор элементарного генома D гексаплоидных пшениц - Ae. tauschii - произрастает во всех районах Закавказья ${ }^{1}$, где растет дикая и широко возделываются культурные тетраплоидные пшеницы. Анализируя перекрывание ареалов этих видов, их полиморфизм и легкую скрещиваемость, Владимир Филимонович вполне обоснованно считал, что межродовая гибридизация с появлением аллогексаплоидных амфидиплоидов могла произойти в данном регионе, так как спонтанная гибридизация пшениц с эгилопсами совершается здесь до сих пор (Dorofeev, 1968). К сожалению, она происходит и на посевах в генетических банках (Holubec et al., 2019).

При обследовании полей был также выявлен ряд форм, четко уклоняющихся от исходных популяций по одному или нескольким признакам. В их числе были обнаружены твердые пшеницы с гладкими остями, безостые и полуостистые, ветвистоколосые, со скверхедным типом колоса, одноостые полбы и многочисленные спельтоиды. Их весьма редкая встречаемость дала основание предположить мутационное происхождение этих форм (Дорофеев, 19686). Наиболее сложный состав популяций и максимальное разнообразие спонтанных гибридов обнаруживаются в предгорной зоне: до 600-800 м над уровнем моря. По материалам закавказских сборов В.Ф. Дорофеев выявил и описал много ранее неизвестных ботанических форм, расширивших представления о внутривидовом разнообразии рода Triticum. В их

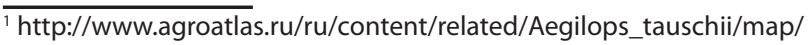

числе подвид твердой пшеницы $T$. durum ssp. caucasicum Dorof. и новые разновидности полбы, спельты, тургидума, твердой, мягкой и карликовой пшениц.

Важным для построения филогении пшениц было обнаружение в Закавказье гораздо большего разнообразия гексаплоидного $(2 n=42)$ вида T. spelta, чем сообщалось ранее другими исследователями. В.Ф. Дорофеев описал 29 новых разновидностей спельты, отнеся их к азиатскому подвиду этого вида - T. spelta L. ssp. kuckuckianum Gökgol. Некоторые из обнаруженных и впервые описанных разновидностей были названы в честь известных отечественных тритикологов: T. spelta L. var. flaksbergeri Dorof., T. spelta L. var. vavilovii Dorof. (рис. 1, a), T. spelta L. var. dekaprelevichii Dorof., (см. рис. 1, 6), T. spelta L. var. menabdii Dorof., T. spelta L. var. mustaphaevii Dorof., T. spelta L. var. thumanianii Dorof., T. spelta L. var. zhukovskyi (рис. 2, a), T. spelta L. var. sinskajae Dorof. (см. рис. 2, 6), T. spelta L. var. jakubzinerii Dorof. (рис. 3, a). Следует особо упомянуть о разновидности спельты - T. spelta var. marinae Dorof. (см. рис. 3, б) (Дорофеев, 19706), которая была названа в честь Марины Петровны Ананьевой, работавшей еще при Н.И. Вавилове и ставшей главной помощницей Владимира Филимоновича в изучении пшениц Закавказья. Сборы растительного разнообразия Закавказья, проведенные им в 1961-1964 гг., были хорошо документированы (см. рис. 1-3).

Собственные данные и обобщение результатов других исследователей позволили В.Ф. Дорофееву воссоздать полную картину разнообразия пшениц и эгилопсов, имеющегося в этом регионе. Было показано, что здесь сосредоточено все видовое богатство рода Triticum, за исключением лишь видов T. dicoccoides (Körn. ex Asch. \& Graebn.) Schweinf., T. ae- 

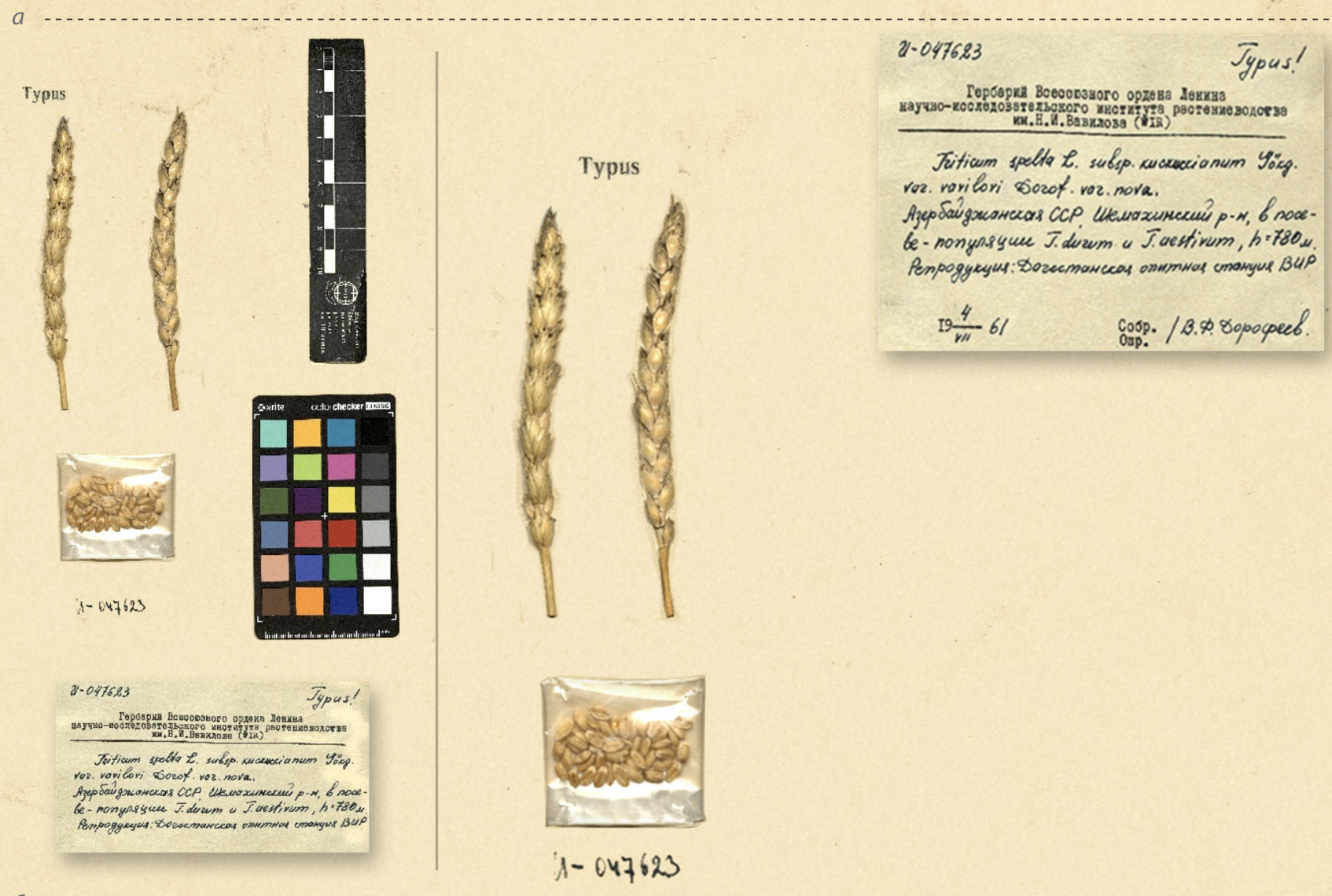

6

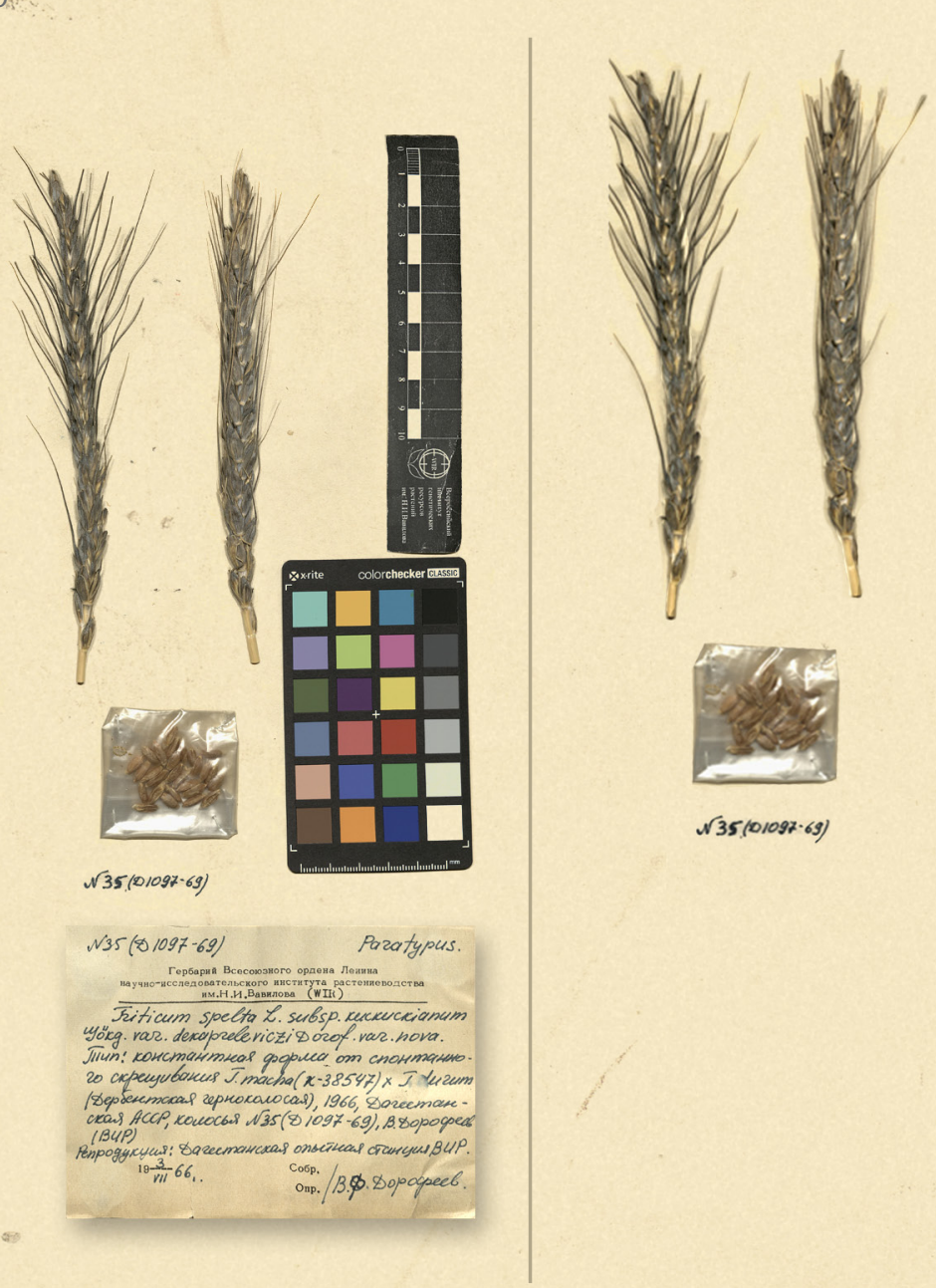

Рис. 1. Гербарные экземпляры новых форм пшениц, описанных В.Ф. Дорофеевым (на примере Triticum spelta): $a$ - Triticum spelta L. var. vavilovii Dorof. var. nova (по: (Чухина, 2019)); 6 - Triticum spelta L. var. dekaprelevichii Dorof. var. nova. Гербарий ВИР

Fig. 1. Herbarium specimen of the new varieties of wheats described by V.F. Dorofeev (on example of Triticum spelta): $a$ - Triticum spelta L. var. vavilovii Dorof. var. nova (from (Chukhina, 2019)); b - Triticum spelta L. var. dekaprelevichii Dorof. var. nova. The VIR herbarium 

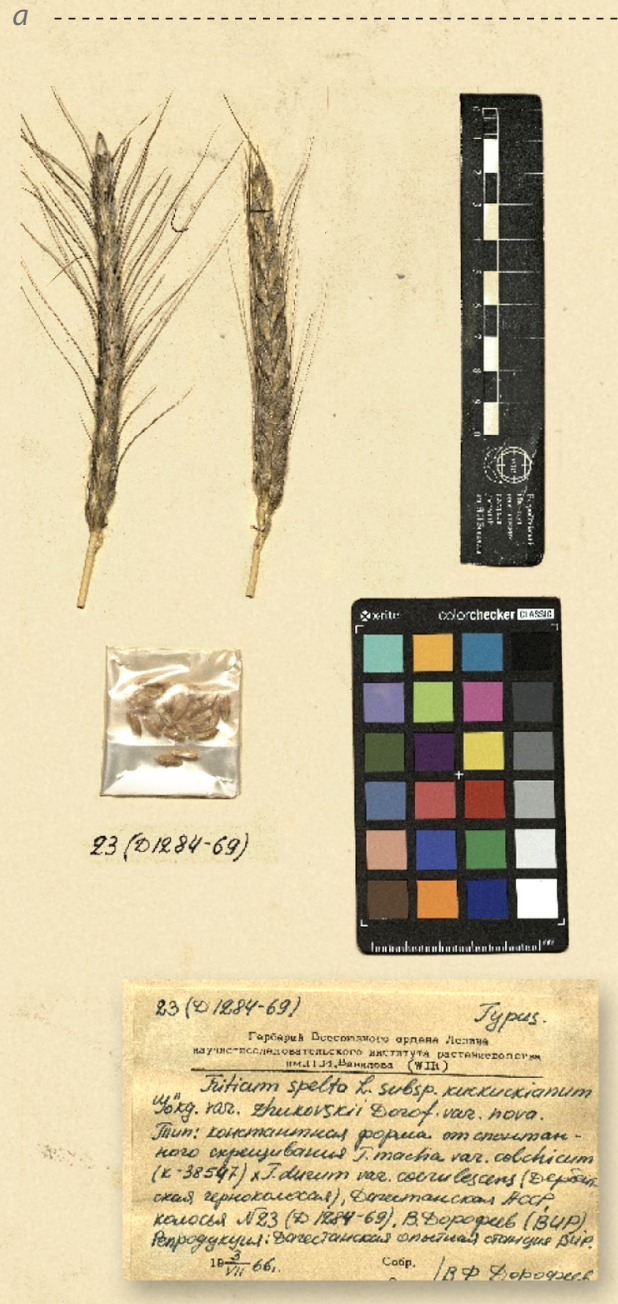
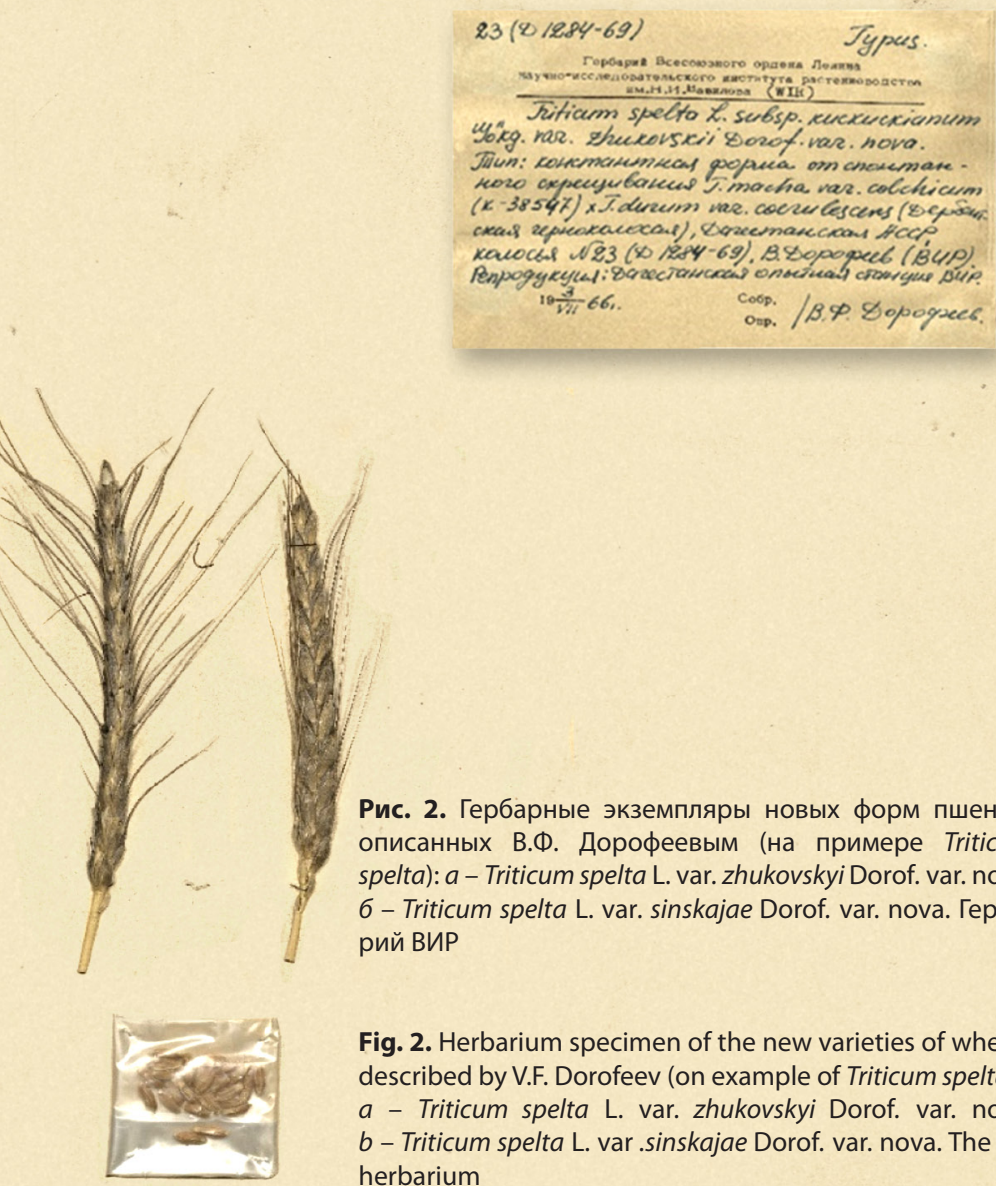

Fig. 2. Herbarium specimen of the new varieties of wheat described by V.F. Dorofeev (on example of Triticum spelta): a - Triticum spelta L. var. zhukovskyi Dorof. var. nova; $b$ - Triticum spelta L. var .sinskajae Dorof. var. nova. The VIR herbarium

Рис. 2. Гербарные экземпляры новых форм пшениц описанных В.Ф. Дорофеевым (на примере Triticum 6 - Triticum spelta L. var. sinskajae Dorof. var. nova. Гербарий ВИР

$23(21284-69)$
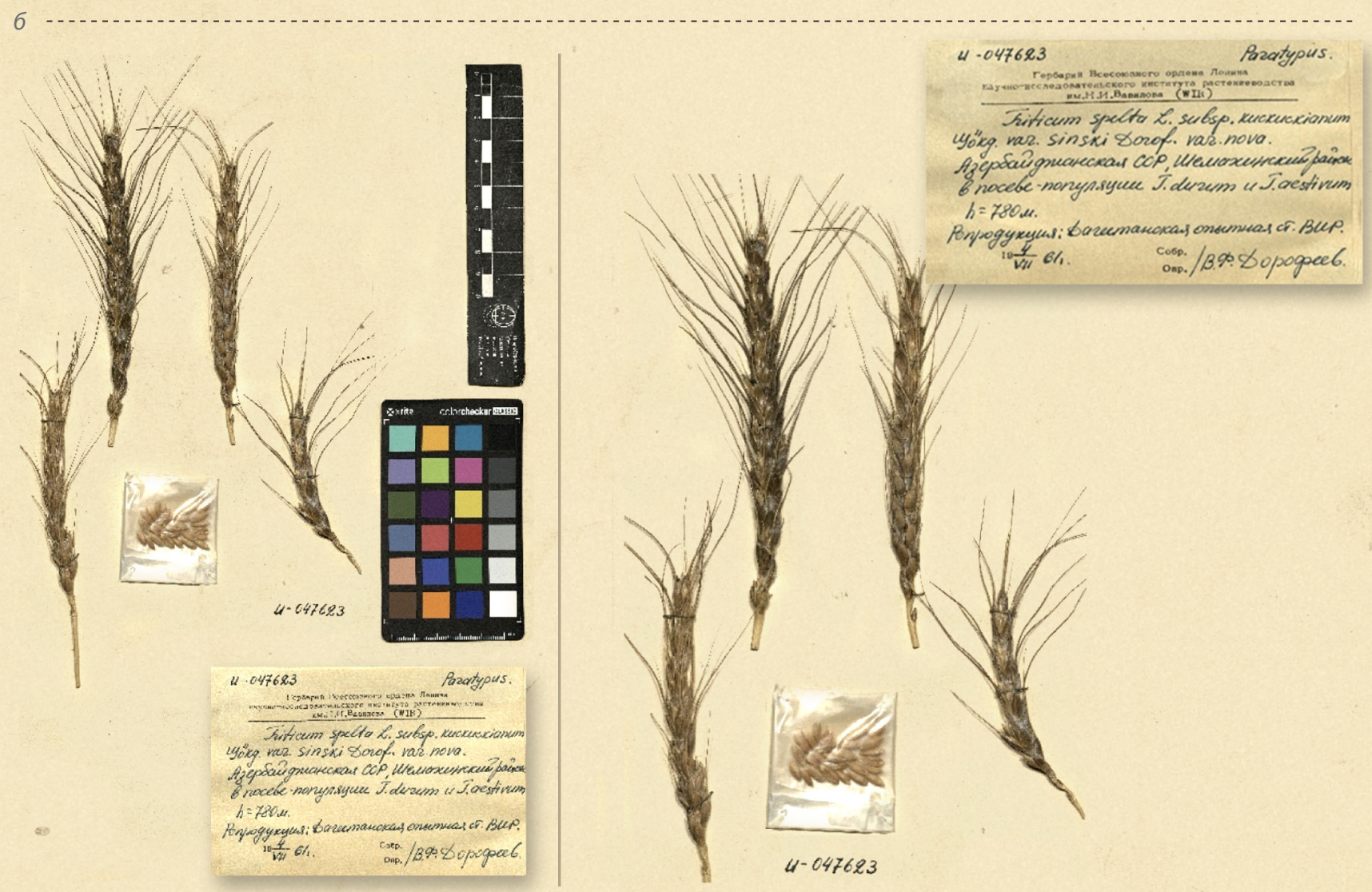

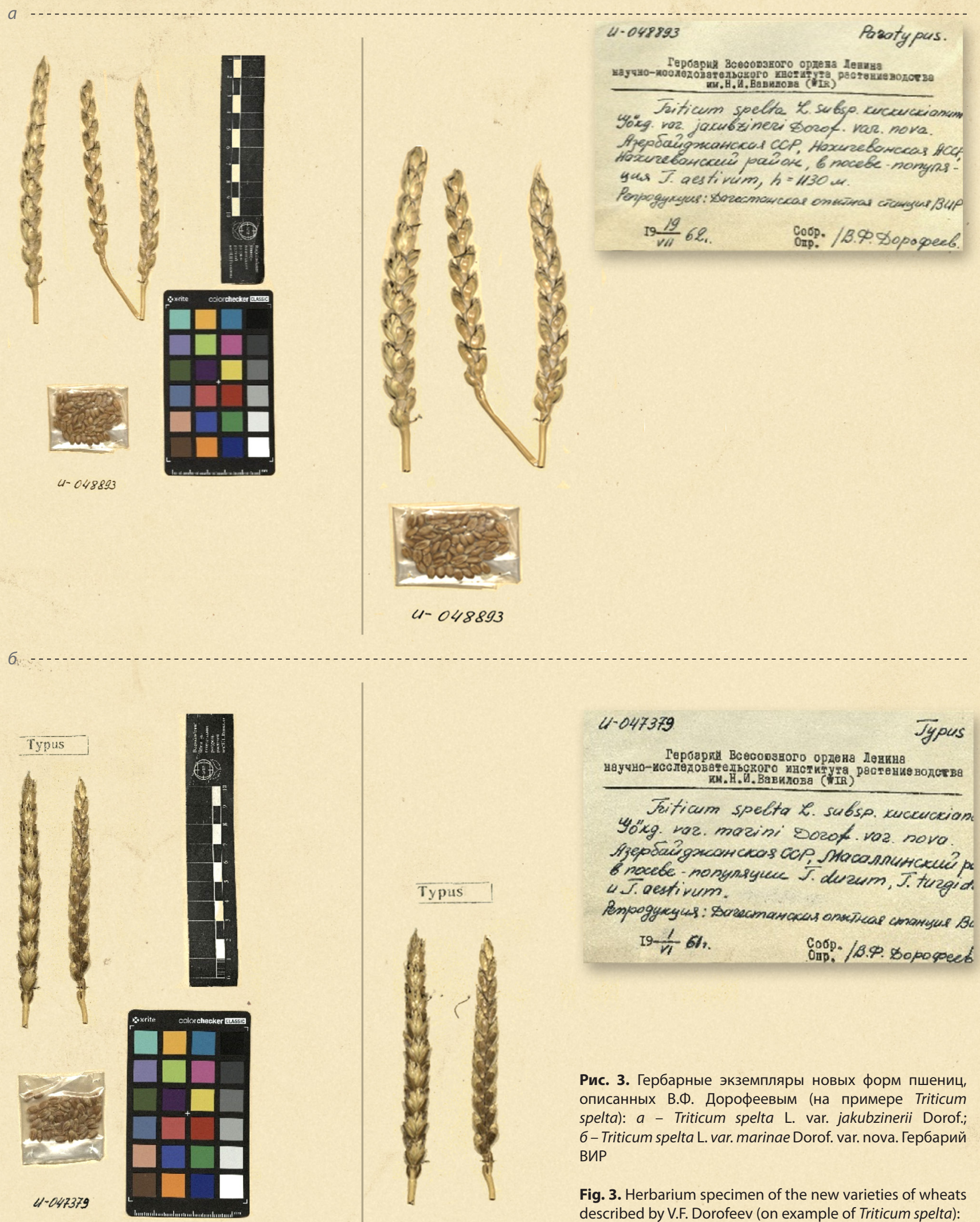

11-047379

Героарқан Bceconszoro ордена Левине

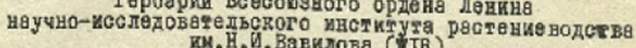

Fiticum spelta L. subsp. xuacuction Yo"kg. raz. marini Dorof. 102 nova.

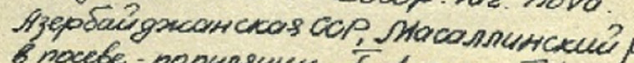
\&nocebe - nongnsyuer S. duarm, J. turaid 4 T. aestivum.

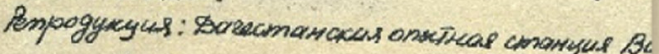
I9 $\frac{1}{17} 67$

Corp. / 8.9 . Dopospeed

Рис. 3. Гербарные экземпляры новых форм пшениц, описанных В.Ф. Дорофеевым (на примере Triticum spelta): a - Triticum spelta L. var. jakubzinerii Dorof.; б - Triticum spelta L. var. marinae Dorof. var. nova. Гербарий BИP

Fig. 3. Herbarium specimen of the new varieties of wheats described by V.F. Dorofeev (on example of Triticum spelta): $a$ - Triticum spelta L. var. jakubzinerii Dorof.; $b$ - Triticum spelta L. var. marinae Dorof. var. nova. The VIR herbarium 
thiopicum Jakubz., T. sphaerococcum Perciv. и T. ispahanicum Heslot. В число эндемиков Закавказья входят T. timopheevii (Zhuk.) Zhuk., T. militinae Zhuk. et Migusch., T. persicum (син. T. carthlicum), T. macha Dekapr. et Menabde, T. zhukovskyi Menabde et Ericzjan, T. vavilovii Jakubz. В Закавказье насчитывается более 400 разновидностей пшеницы, значительное число хорошо дифференцированных подвидов и эколого-географических групп. Такого обширного внутривидового полиморфизма нет в других регионах мира. В 1924 г. П.М. Жуковский описал в Закавказье лишь 9 видов пшеницы и 78 их разновидностей. С тех пор наши знания о разнообразии пшениц Закавказья значительно расширены, и в этом большая заслуга принадлежит В.Ф. Дорофееву. Опираясь на свои многолетние исследования он пришел к ряду важных выводов и был убежден, что «первичным центром происхождения пшениц является территория стран Передней Азии» (Дорофеев, 1971в, с. 63), а «центральным плацдармом эволюции видов пшеницы в этом центре следует признать территории Закавказья, Турции и Ирана» (там же, с. 63). После его работ стало общепризнанным, что Закавказье - центр видового и внутривидового разнообразия, происхождения и активный очаг формообразования пшеницы. Здесь выявлен ценнейший материал для селекционного использования по многим хозяйственно важным признакам (Дорофеев, Мережко, 1971; и др.).

Результаты исследований В.Ф. Дорофеева публиковали не только отечественные, но и известные зарубежные научные журналы (Dorofeev, 1968, 1969а-с, 1971). Они легли в основу его докторской диссертации (Дорофеев, 1971в). Наиболее полная сводка полученных данных опубликована в обобщающей монографии «Пшеница Закавказья» (Дорофеев, 1972). Очень важным результатом «закавказского» периода его научной деятельности стало то, что он кардинально расширил знания о разнообразии и филогении пшениц, стал опытнейшим знатоком этой культуры, осознал всю сложность и комплексность задач, решаемых Институтом, и приобрел широкую известность среди тритикологов и специалистов по культурной флоре.

Опыт, накопленный при изучении пшениц Закавказья, В.Ф. Дорофеев привнес в исследование всего мирового генофонда рода Triticum, сосредоточенного в коллекции ВИР. Под его руководством сотрудники отдела пшениц ВИР описали целый ряд ранее неизвестных науке видов пшеницы: T. etropavlovskyi Udacz. et Migusch. (Удачин, Мигушова, 1970), T. jakubzineri Udacz. et Schachm. (Удачин, Шахмедов, 1972), T. sinskajae A. Filat. et Kurk. (Филатенко, Куркиев, 1975) и T. kiharae Dorof. et Migusch. (Дорофеев, Мигушова, 1977) и сотни новых ботанических разновидностей, что позволило заполнить недостающие звенья в вавиловских гомологических рядах наследственной изменчивости.

Еще в начале $X X$ в. существовало представление об участии видов рода Aegilops L. в становлении полиплоидной пшеницы (Percival, 1921). В своих работах с ведущими учеными ВИР В.Ф. Дорофеев уделял много внимания разнообразным аспектам эволюции рода Triticum и предполагаемым источникам ее элементарных геномов (Берлянд-Кожевников, Дорофеев, 1976; Дорофеев, Берлянд-Кожевников, 1977; Дорофеев, Мигушова, 19816). Он был координатором про- граммы комплексного изучения видового и внутривидового разнообразия родов Triticum и Aegilops современными биохимическими, молекулярно-биологическими, генетическими, физиологическими, иммунологическими, анатомическими, цитологическими и другими методами. Позже эту работу продолжили его ученики и коллеги (Мережко и др., 1999). Особый импульс исследованиям придало участие в них сотрудников отдела молекулярной биологии ВИР, руководимого академиком ВАСХНИЛ В.Г. Конаревым (Конарев и др., 1978). Иммунохимический и электрофоретический анализы белков у многих сотен образцов из мировой коллекции пшеницы и эгилопса позволили найти «белковые радикалы» видов, уточнить геномные формулы этих видов и воссоздать пути эволюции рода Triticum (Конарев, 1980, 1983). Впервые было показано, что пшеница имеет два разнокачественных генома $A-A^{u}$ и $A^{b}$, носителями которых являются дикие однозернянки: $A^{u}-T$. urartu и $A^{b}-T$. boeoticum Boiss. (Конарев А.В. и др., 1974; Конарев В.Г. и др., 1976). Эти данные подтвердили предположение Н.И. Вавилова и К.А. Фляксбергера о дифилетическом происхождении пшеницы и позволили предложить новую систему рода Triticum, включающую два полиплоидных ряда (Конарев и др., 1978; Дорофеев и др., 1979; Дорофеев, Мигушова, 19816; Dorofeev, Miguschowa, 1983a, b). Впоследствии эта система была подкреплена результатами исследований других лабораторий ВИР и стала хорошим путеводителем для специалистов по растительным ресурсам и селекционеров в мировом генофонде пшеницы и ее сородичей. В настоящее время ее основные положения используются в современных системах рода Triticum (Goncharov, 2011; Hammer et al., 2011; и др.).

Весьма перспективной оказалась гипотеза синтеза новых аллополиплоидов пшеницы, которые могли бы заполнить все недостающие звенья в ее полиплоидных рядах (Берлянд-Кожевников, Дорофеев, 1976; Дорофеев, БерляндКожевников, 1977; Конарев и др., 1978; Дорофеев и др., 1979; Дорофеев, Мигушова, 1981б; Мережко, 1986). Из геномов Triticum и Aegilops ( $A^{\mathrm{u}}, \mathrm{A}^{\mathrm{b}}, \mathrm{C}, \mathrm{C}^{\mathrm{u}}, \mathrm{D}, \mathrm{M}, \mathrm{M}^{\mathrm{u}}, \mathrm{M}^{\mathrm{t}}, \mathrm{S}(\mathrm{G}), \mathrm{S}^{\mathrm{b}}\left(\mathrm{B}^{\mathrm{b}}\right), \mathrm{S}^{1}\left(\mathrm{~B}^{\prime}\right)$ и $\left.\mathrm{S}^{\mathrm{s}}\left(\mathrm{B}^{\mathrm{s}}\right)\right)$, носители которых способны формировать зерно хлебного типа, в аллоплоидные геномы пшеницы включены только пять: $\mathrm{A}^{\mathrm{u}}, \mathrm{A}^{\mathrm{b}}, \mathrm{B}, \mathrm{G}$ и D. Еще меньше в геном возделываемых пшениц включено типов цитоплазм (Tsunewaki, 2009, 2010). Таким образом, оставался еще очень большой резерв для синтеза аллополиплоидов с новыми комбинациями геномов и цитоплазм. В настоящее время эта идея успешно реализуется в ряде генетических лабораторий мира (Goncharov et al., 2007), способствуя обеспечению селекционеров новым оригинальным исходным материалом (Bhatta et al., 2019).

Знание мирового генофонда пшениц позволило В.Ф. Дорофееву взяться за решение еще одной исключительно сложной задачи. Он возглавил работу по изданию уникальной коллективной монографии «Культурная флора СССР, Т. 1. Пшеница», в которой представлена последняя система ВИР рода Triticum (Дорофеев и др., 1979). При этом Владимир Филимонович сам участвовал в разработке систематики 23 видов, описании многих новых таксонов и уточнении ботанического диагноза примерно 180 ранее описанных разновидностей. В монографии обобщена обширная ин- 


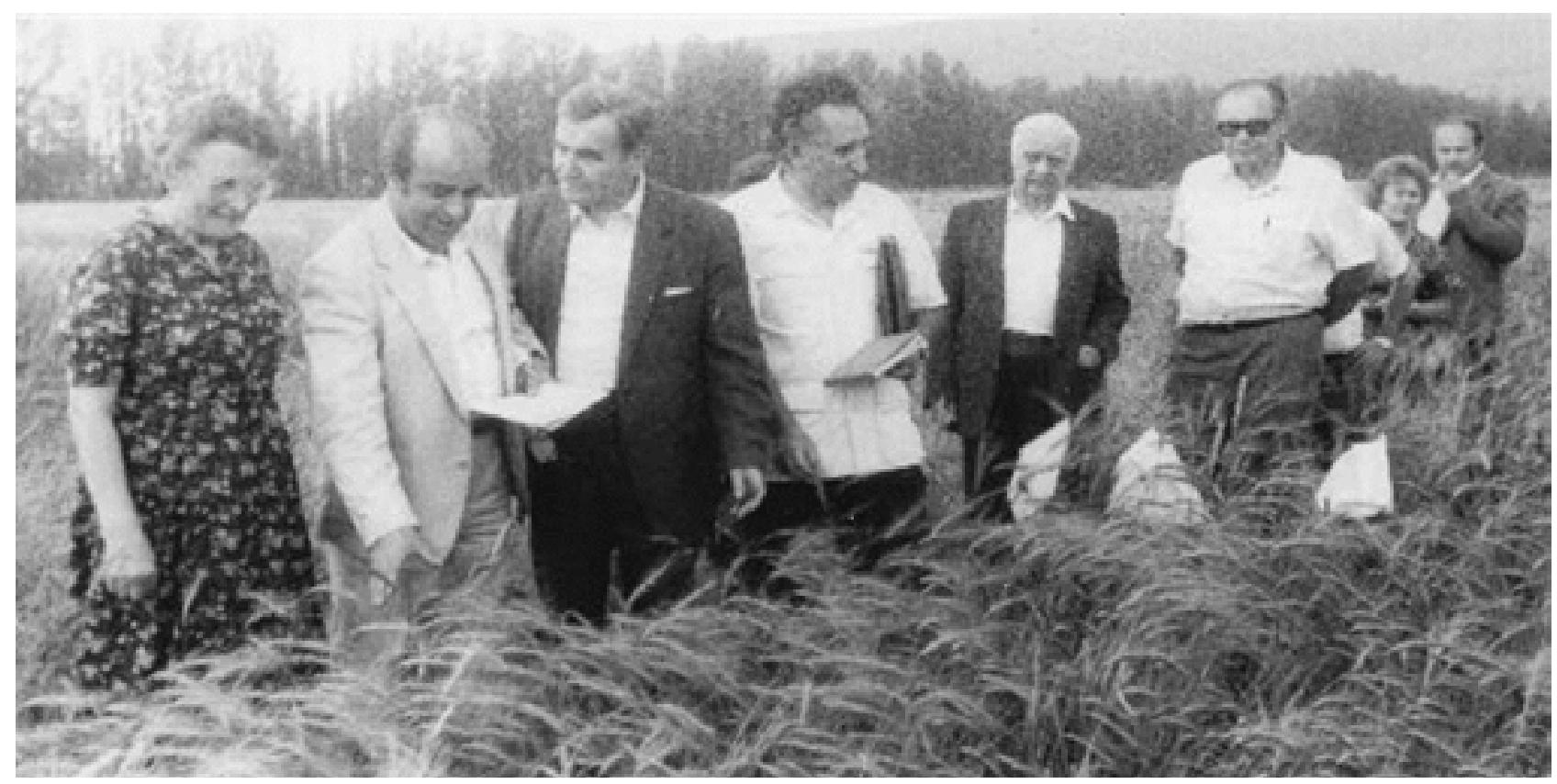

Совещание. Дагестанская опытная станция ВИР, пшеничные поля (1982). Слева направо: зав. кафедрой генетики Ленинградского СХИ профессор Зинаида Васильевна Абрамова, проректор по учебной работе декан агрофака Грузинского СХИ профессор Петр Павлович Наскидашвили, директор ВИР академик ВАСХНИЛ Владимир Филимонович Дорофеев, зав. кафедрой ботаники и селекции Ереванского СХИ профессор Папин Арташесович Гандилян, зав. отделом молекулярной биологии ВИР академик ВАСХНИЛ Василий Григорьевич Конарев, ученый секретарь ВИР профессор Роальд Арсентьевич Удачин

Dagestan VIR station meeting, wheat fields (1982). Professor, head of the department of genetics of Leningrad Agricultural Institute Zinaida V. Abramova, vice-rector for academic affairs, dean of the agronomy faculty of the Georgian Agricultural Institute, professor Petr P. Naskidashvili, VIR director, academician V.F. Dorofeev, head of the department of botany and breeding of the Erevan Agricultural Institute, professor Papin A. Gandilyan, head of the department of molecular biology VIR, academician Vasily G. Konarev, VIR scietific secretary, professor Roald A. Udachin

формация по общей характеристике рода Triticum, его эволюции и истории систематики, ботанической характеристике видов, их филогении, происхождению, географическому распространению и значимости для селекции. Описанная в монографии система рода пшеницы включает 2 подрода, 6 секций и 27 видов, объединенных в 10 групп. В ней также учтены уникальность геномов и уровень плоидности видов. Выделение двух подродов - Triticum и Boeoticum Migusch. et Dorof. - было основано на идее дифилетического происхождения тетраплоидных видов, согласно которой первыми аллополиплоидами в процессе эволюции пшеницы были сохранившиеся в природе дикие полбы T. dicoccoides с геномами $\mathrm{A}^{\mathrm{u}}$ и B и T. araraticum Jakubz. с геномами $\mathrm{A}^{\mathrm{b}}$ и G. B настоящее время показано, что геном A T. araraticum - тоже Au (Dvořák et al., 1993). Деление на секции обусловлено peзультатами геномного анализа, а на группы - признаками «пленчатость» и «голозерность». Система рода снабжена ключами для определения принадлежности форм к таксонам видового и внутривидового рангов, составленными О.Н. Коровиной. Эти ключи построены на морфологических признаках, достаточно стабильно проявляющихся в разнообразных условиях внешней среды. В настоящее время в отделе генетических ресурсов пшеницы разрабатываются идеографические определители (Зуев и др., 1919), позволяющие строить нейронные сети для определения видов (Ге- наев и др., 2018; Genaev et al., 2019).

Монография «Культурная флора СССР, Т. 1. Пшеница» - до сих пор один из самых полных в мире справочников по роду Triticum. Ее публикация стала важным событием, получившим международное признание. На рабочем совещании по таксономии, состоявшемся в рамках 9-го Международного симпозиума по генетике пшеницы в Саскатуне (Канада, август 1998 г.), было принято решение создать в интернете интерактивную базу данных, которая включала бы синонимы видов пшеницы и эгилопса, используемые в наиболее известных системах этих родов ${ }^{2}$. К сожалению, до сих пор международному консорциуму так и не удалось перевести на английский язык эту монографическую обработку рода Triticum, ставшую уже классической (Morrison et al., 2000).

С первых дней своей работы в ВИР В.Ф. Дорофеев уделял особое внимание укреплению и расширению связей отдела пшениц с селекцентрами страны. Вероятно, в связи с этим почти в каждой его работе можно найти сведения об исходном материале для селекции, а многие публикации специально посвящались только этому вопросу (Дорофеев, 19766; Дорофеев и др., 1976, 1977, 1983, 1987). Проводимое комплексное изучение собранного генофонда в экологогеографической опытной сети и проблемных лабораториях 2 Общедоступную ссылку на систему рода Triticum В.Ф. Дорофеева
и его коллег (1979) см. в Википедии (https://en.wikipedia.org/wiki/ и его коллег (1979) см.
Taxonomy_of_wheat). 


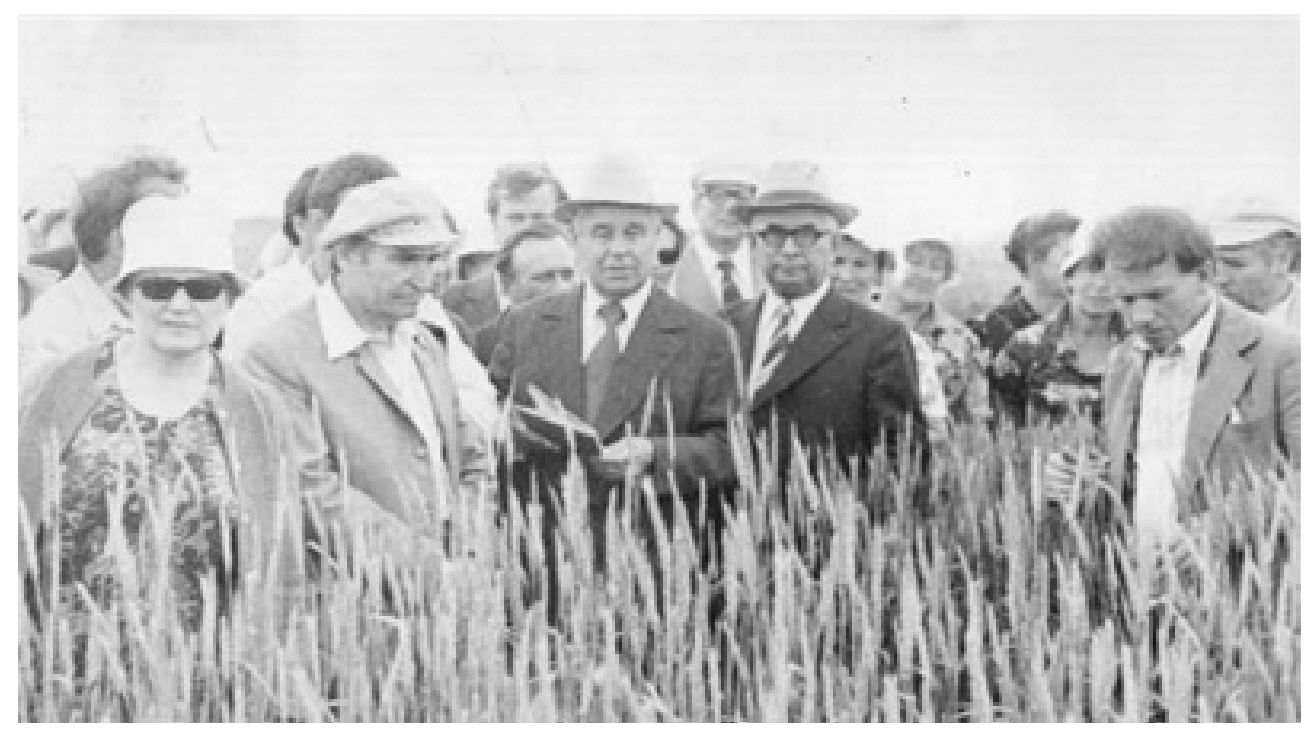

Совещание в Мироновском НИИ селекции пшеницы (1976). Слева направо: зав. кафедрой селекции и семеноводства Ленинградского сельскохозяйственного института профессор Глафира Васильевна Бадина, член-корреспондент ВАСХНИЛ Владимир Филимонович Дорофеев, директор Мироновского института академик Василий Николаевич Ремесло

Meeting at the Mironovsky Wheat Breeding Research Institute (1976). On the front: chair of breeding and seed farming of Leningrad Agricultural Institute, professor Glafira V. Badina, corresponding member of VASKhNIL V.F. Dorofeev, the director of Mironovsky Institute, academician Vasily N. Remeslo

ВИР, его сети, а также в других научно-исследовательских учреждениях страны позволило создать специальные генофонды (типовые коллекции) по наиболее важным для селекции признакам: высокопродуктивные, зимостойкие, засухоустойчивые, иммунные, скороспелые, короткостебельные, устойчивые к полеганию, высококачественные и др. Отдел пшениц ВИР первым начал издавать специальные выпуски каталогов по итогам изучения мировой коллекции и методические указания по актуальным проблемам селекции для их эффективного использования (Дорофеев и др., 1973а, 1974; и др.), а также каталоги с результатами совместного исследования исходного материала с селекционными учреждениями страны. В селекционные центры ежегодно рассылали многие тысячи лучших образцов для решения региональных проблем селекции. Очень важную роль играли ежегодно проводимые полевые семинары с демонстрацией новейших поступлений в коллекцию ВИР и проблемными докладами ведущих ученых Института и других учреждений. Крупным вкладом в развитие теории и практики селекции явилась книга «Пшеницы мира», написанная под руководством В.Ф. Дорофеева и выдержавшая два издания (Пшеницы..., 1976, 1987). Фундаментальное издание «Пшеницы мира», не имеющее аналогов в мире, стало поистине настольной книгой селекционеров нашей страны. Появление этого труда оказалось возможным благодаря тому, что в отделе пшениц были собраны высококвалифицированные специалисты, хорошо знающие коллекцию и поддержи вающие тесные связи с селекционерами: М.М. Якубцинер, М.И. Руденко, Э.Ф. Мигушова, Р.А. Удачин, М.В. Новикова, И.П. Шитова, А.А. Филатенко, Л.В. Семёнова, О.Д. Градчани- нова и др. В монографии обобщен многолетний опыт отечественной и мировой селекции пшеницы, показаны пути использования различных видов в гибридизации, вскрыты закономерности изменчивости и наследования хозяйственно важных признаков при внутри- и межвидовых скрещиваниях, описан наиболее ценный исходный материал для решения крупных селекционных проблем. Сам Владимир Филимонович стал соавтором сорта озимой пшеницы Унумли Бугдай.

С середины 1970-х гг. В.Ф. Дорофеев уделял большое внимание новой синтезированной человеком культуре - тритикале (Дорофеев, Куркиев, 1975, 1977; Дорофеев, 1976б; Дорофеев и др., 1977). По его инициативе образцы тритикале выделили в самостоятельную коллекцию, учитывая возрастающий к ней интерес и специфику работы с ее генофондом. На Дагестанской опытной станции ВИР была организована специальная лаборатория для изучения и обогащения генофонда тритикале за счет вовлечения в скрещивания богатейшего видового и внутривидового разнообразия пшеницы и ржи, имеющегося в коллекции (работой руководил У.К. Куркиев $)^{3}$. К этому времени ВИР имел длительную традицию работы с ржано-пшеничными гибридами (Левитский, Бенецкая, 1931). Коллекция тритикале к 1976 г. насчитывала в постоянном и интродукционном каталогах 2516 образцов почти из 20 стран (Дорофеев и др., 1977). Благодаря усилиям У.К. Куркиева, В.Ф. Дорофеева, Т.В. Охотниковой, Р.А. Удачина, А.А. Филатенко и других сотрудников ВИР пополнение коллекции активно продолжалось и в последующие годы. При этом особое внимание уделяли расширению геогра-

${ }^{3}$ http://www.vir.nw.ru/kurkiev-ullubij-kishtilievich/ 


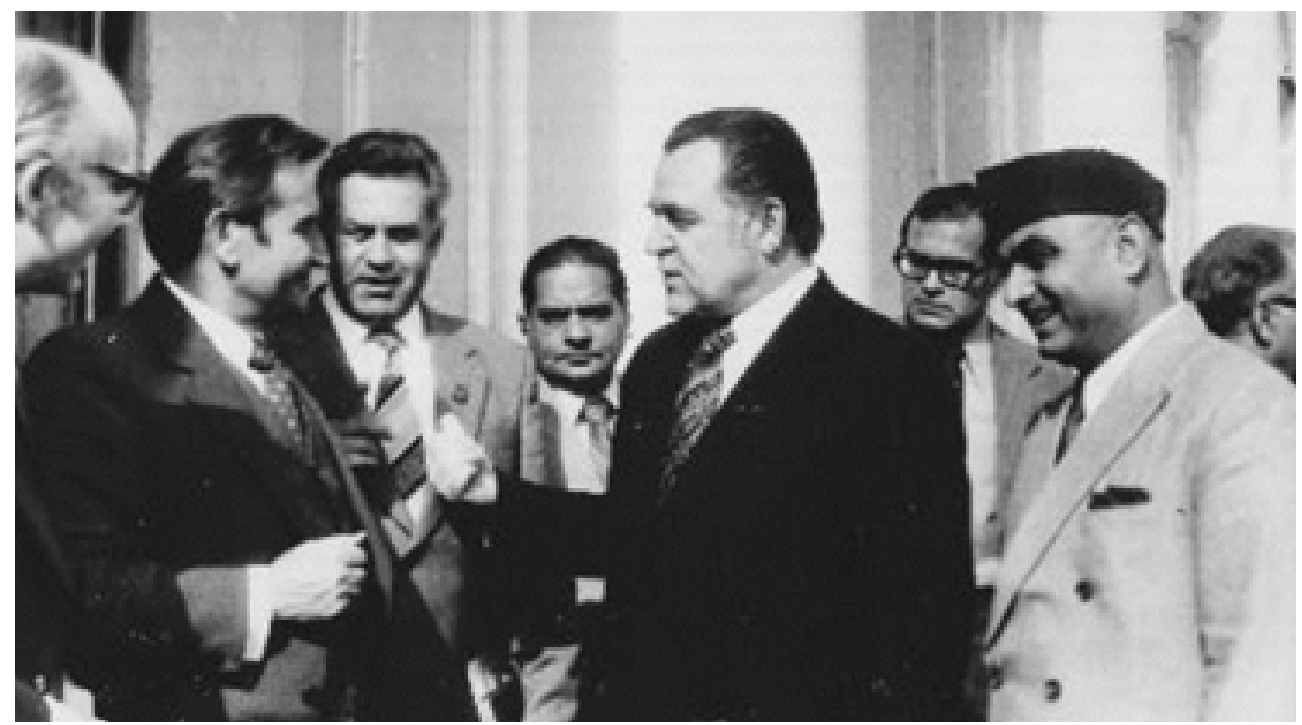

На встрече с делегацией специалистов из Индии. ВИР (1977)

At a meeting with a delegation of experts from India. VIR (1977)

фии и генетического разнообразия собираемого материала (Куркиев и др., 2008). В настоящее время в коллекции тритикале ВИР достаточно полно представлено созданное в мире многообразие форм, включая наиболее значимые сорта и ценные селекционные линии. Она насчитывает 4211 образцов из 47 стран, включая 91 \% гексаплоидных, 6 \% октоплоидных и 3 \% тетраплоидных форм. Эту коллекцию активно используют селекционеры страны и ближнего зарубежья. Более половины включенных в Госреестр РФ сортов тритикале создано с участием образцов ВИР (Государственный реестр..., 2019). Владимир Филимонович является соавтором кормового сорта Узор, районированного в Узбекистане.

На основе анализа имеющегося разнообразия тритикале и геномного состава изучаемых форм В.Ф. Дорофеев совместно с Т.В. Охотниковой и Э.Ф. Мигушовой предложили в 1982 г. первый вариант системы рода Triticale Müntzing (син. ×Triticosecale Wittm.) (Дорофеев и др., 1982). К сожалению, эта работа осталась незавершенной (Уколов и др., 2006).

В.Ф. Дорофеев активно занимался пополнением коллекции отдела пшениц новым материалом. О результатах обследования им Закавказья уже было сказано выше. Кроме того, он провел целую серию экспедиций в зарубежные страны: Турцию (1964), Иран (1968), Индию (1969), Пакистан (1971), Бурунди, Сомали, Кению (1972), Италию (1973), Англию (1974, 1977), Сирию и Ирак (1974), ГДР (1974), Венгрию (1974, 1977) и другие (Щербаков, Чикова, 1970; Ляпунова, 2019; и др.). В коллекцию ВИР было доставлено более 6.5 тыс. образцов пшеницы и других сельскохозяйственных культур. Особый интерес В.Ф. Дорофеев проявлял к регионам, входящим в центр происхождения гексаплоидных пшениц. Собранный здесь материал представлял особую ценность для раскрытия потенциала этой культуры. Благодаря предпринятым усилиям, коллекция пшеницы, эгилопса и тритикале, сосредоточенная в ВИР, стала одной из наиболее крупных и репрезентативных коллекций мира. В ней пред- ставлены богатейшее видовое и внутривидовое разнообразие форм, местные популяции, сорта и линии более чем из 70 стран пяти континентов. В поисках нового разнообразия возделываемых растений В.Ф. Дорофеев неизбежно сталкивался с фактами обеднения некоторых местных популяций. Впервые он обнаружил это в Закавказье. В 1962-1964 гг. ему удалось найти только пять из десяти разновидностей T. monococcum L., выявленных здесь ранее (Дорофеев, 19716). Он объяснил это тем, что данный вид постепенно исчезает из культуры даже в горных районах. В Закавказье Владимир Филимонович смог также найти лишь семь видов эгилопса: Ae. biuncialis (Vill.) Vis., Ae. triuncialis L., Ae. triaristata Willd., Ae. cylindrica Host, Ae. squarrosa L. (син. Ae. tauschii Coss.), Ae. ovata L., Ae. columnaris Zhuk. из 12 упоминавшихся другими исследователями (Дорофеев, Мигушова, 1966; Дорофеев и др., 1969). В дальнейшем он наблюдал факты исчезновения ценных форм и местных сортов пшеницы в странах Передней Азии, Ближнего Востока и Африки. Учитывая опасность такой тенденции, В.Ф. Дорофеев на всех уровнях поднимал вопрос о необходимости бережного сохранения биоразнообразия культурных растений и их диких сородичей в национальных заповедниках, заказниках, природных изолятах и генетических банках мира. В настоящее время эту обеспокоенность разделяет все международное сообщество. Проблема предотвращения генетической эрозии растительных ресурсов стала доминирующей в деятельности генбанков. Для ее решения осуществляются многочисленные международные и национальные программы сохранения биоразнообразия in situ и ех situ.

В своих публикациях, лекциях, докладах, беседах и консультациях В.Ф. Дорофеев выступал как умелый пропагандист научных знаний. Он писал легко и доходчиво, опубликовал более 300 работ. Кроме того, под его редакцией вышло четыре тома «Культурной флоры СССР», 11 монографий, 54 каталога ВИР, 51 том «Трудов по прикладной бота- 
нике, генетике и селекции», 60 выпусков «Бюллетеня ВИР», 13 методических указаний и пособий 4 . Наряду с изложением собственных научных достижений В.Ф. Дорофеев уделял много внимания пропаганде творческого наследия Р.Э. Регеля, Н.И. Вавилова, К.А. Фляксбергера, П.М. Жуковского и других ученых, показывая роль их идей в успешном развитии современных исследований (Дорофеев, 19696, 1979, 1980а-в, 1985a, 1986; Лобанов и др., 1978; Дорофеев, Мигушова, 1981а; Дорофеев и др., 1987; Дорофеев, Филатенко, 1987). Эти его публикации служат хорошим путеводителем для знакомства с творчеством основателей учения о генетических ресурсах растений. Проводя экспедиционные сборы культурных растений и их сородичей в зарубежных странах, он знакомился с сельскохозяйственным производством этих стран, применяемыми наукоемкими технологиями, достижениями биологической и сельскохозяйственной науки, анализировал состояние и перспективы местной селекции. Результаты он издавал в информационных статьях (Дорофеев, 1971г; Дорофеев, Агафонов, 1973; Дорофеев, Корсаков, 1973; Дорофеев, Атланов, 1981; Дорофеев, Ядров, 1981). Эти публикации представляли большой интерес как наиболее свежие, а часто и единственные полные источники сведений о растениеводстве в тех или иных странах. Ряд его работ посвящен популяризации научных знаний. Наиболее показательна брошюра «У истоков высоких урожаев» (Дорофеев, 19856), предназначенная для тружеников агропромышленного комплекса. В ней наглядно и очень образно показано, как вавиловские идеи и труд ученых ВИР можно реализовать для увеличения урожаев.

На конгрессах, конференциях, симпозиумах и совещаниях Владимир Филимонович умел покорять аудиторию своими докладами. Тематика его выступлений всегда была актуальной. Она затрагивала самые разнообразные аспекты сбора, сохранения, изучения и использования мирового разнообразия культурных растений и их диких сородичей. Важное значение в пропаганде научных знаний имело личное общение В.Ф. Дорофеева со многими учеными. Его интеллигентность, обаяние, доброжелательность, скромность, постоянная готовность поделиться своими знаниями делали центром притяжения сначала возглавляемый им отдел пшениц ВИР, а затем и весь Институт. Редкий день обходился без того, чтобы кто-нибудь из ученых не приезжал встретиться с Владимиром Филимоновичем, узнать о последних достижениях Института, получить консультацию, расспросить о новом материале. География работы его гостей не ограничивалась пределами нашей страны, простиралась почти на все страны мира. Трудно даже перечислить всех крупных ученых, которые были его близкими друзьями. Все это способствовало широкому распространению вировских идей и развитию плодотворных научных связей.

Владимир Филимонович был одним из наиболее талантливых учеников академика ВАСХНИЛ П.М. Жуковского. Сам он тоже стал опытным учителем молодых исследователей, решивших связать свою жизнь с наукой. Под его руководством подготовлено и успешно защищено более 30 диссертаций по очень разнообразной тематике ${ }^{5}$. Обращает на себя внимание широчайшая география этих работ. Это объясня-

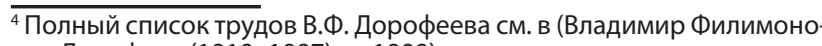
вич Дорофеев (1919-1987)..., 1999).

${ }^{5}$ http://www.vir.nw.ru/vir-v-licah ется тем, что он готовил специалистов в области генетических ресурсов растений не только для системы ВИР, но и для селекционных центров страны. Работы его аспирантов были составной частью программы всестороннего изучения коллекции ВИР в различных эколого-географических условиях и служили ценным источником информации для поиска нужного селекционерам исходного материала.

В.Ф. Дорофеев был очень демократичен в отношениях со своими учениками, постоянно поощряя их к смелому выдвижению и отстаиванию новых идей, инициативности. Обычно он определял тему диссертационной работы и отпускал ее исполнителя в «свободное плавание», приходя на помощь лишь в самые трудные моменты. Такая методология способствовала отбору людей, умеющих самостоятельно принимать нужные решения и находить выход из самых сложных ситуаций. Ныне многие бывшие аспиранты Владимира Филимоновича стали ведущими учеными в научных учреждениях России и других стран. Они плодотворно развивают идеи своего учителя в различных областях биологической и сельскохозяйственной наук.

Много времени и сил В.Ф. Дорофеев тратил на организационную и общественную работу. С марта 1979 г. к его заведованию самым крупным отделом Института добавилась должность директора ВИР - самого крупного научного учреждения в системе ВАСХНИЛ. Кроме того, Владимир Филимонович был заместителем председателя секции зерновых культур ВАСХНИЛ, а также входил в состав Координационного совета по селекции пшеницы, Международного комитета по пшенице при Совете по генетическим ресурсам ФАО, Административного совета и исполкома EUCARPIA, HTC по генетическим ресурсам и Совета по селекции и семеноводству сельскохозяйственных культур стран-членов СЭВ. Он был членом редколлегий журналов «Вестник сельскохозяйственной науки», «Селекция и семеноводство», «Доклады ВАСХНИЛ» и нескольких ученых советов.

В.Ф. Дорофеев, придя в науку в 33-летнем возрасте, проделал путь от аспиранта до академика ВАСХНИЛ, от ассистента кафедры ТСХА до директора известного всему миру института, стал одним из ведущих тритикологов мира. За научный вклад в развитие биологической и сельскохозяйственной наук он был награжден орденами Трудового Красного Знамени и «Знак Почета», восемью медалями.

Владимир Филимонович умер 12 марта 1987 г. Однако, как и прежде, в отдел пшениц ВИР со всех концов мира приходят запросы на оттиски его работ. Идеи В.Ф. Дорофеева живут и помогают находить ответы на волнующие вопросы. Новые поколения тритикологов еще долго будут обращаться к его научному наследию, а все, кто знал его лично, хранить светлые воспоминания о выдающемся ученом и прекрасном человеке.

\section{Список литературы / References}

Альдеров А.А. Генетика короткостебельности тетраплоидных пшениц. СПб., 2001.

[Al'derov A.A. Genetics of Dwarfness in Tetraploid wheat. St. Petersburg, 2001. (in Russian)]

Берлянд-Кожевников В.М., Дорофеев В.Ф. О виде и филогенетических отношениях в роде Triticum L. Tp. по прикл. ботанике, генетике и селекции. 1976;58(2):3-18.

[Berlyand-Kozhevnikov V.M., Dorofeev V.F. About species and phylogenetic relationships in the genus Triticum L. Trudy po Prikladnoy 
Botanike, Genetike i Selektsii = Proceedings on Applied Botany, Genetics and Breeding. 1976;58(2):3-18. (in Russian)]

Беспалова Л.А. Реализация модели полукарликового сорта академика П.П. Лукьяненко и ее дальнейшее развитие. Пшеницы и тритикале. Краснодар, 2001:60-71.

[Bespalova L.A. Implementation of the semidwarf variety model by academician P.P. Lukyanenko and its further development. Wheat and Triticale. Krasnodar, 2001:60-71. (in Russian)]

Владимир Филимонович Дорофеев (1919-1987): Биобиблиографический указатель деятелей науки. Сост. Чикида Н.Н., Шорец Н.М. СПб., 1999.

[Vladimir Filimonovich Dorofeev (1919-1987): Bibliography of Scientists. Compiled by Chikida N.N., Shorets N.M. St. Petersburg, 1999. (in Russian)]

Генаев М.А., Комышев Е.Г., Фу Хао, Гончаров Н.П., Афонников Д.А. SpikeDroidDB - информационная система для аннотации морфометрических характеристик колоса пшеницы. Вавиловский журнал генетики и селекции. 2018;22(1):132-140. DOI 10.18699/ VJ18.340.

[Genaev M.A., Komyshev E.G., Fu Hao, Koval V.S., Goncharov N.P., Afonnikov D.A. SpikeDroidDB - information system for annotation of morphometric characteristics of wheat spike. Vavilovskii Zhurnal Genetiki i Selektsii - Vavilov Journal of Genetics and Breeding. 2018;22(1):132-140. DOI 10.18699/VJ18.340. (in Russian)]

Гончаров Н.П. К 125-летию со дня рождения выдающегося ботаника Петра Михайловича Жуковского. Генетика. 2013;49(5):549-557. DOI 10.7868/S0016675813050068.

[Goncharov N.P. 125th birth anniversary of the outstanding botanist Peter Mikhailovich Zhukovsky. Genetika = Genetics (Moscow). 2013, 49(5):549-557. DOI 10.7868/S0016675813050068. (in Russian)]

Государственный реестр селекционных достижений, допущенных к использованию. Т. 1. Сорта растений (официальное издание). М.: ФГБНУ «Росинформагротех», 2019.

[The State Register of Breeding Achievements Allowed for Use. Vol. 1. Plant Varieties (official publication). Moscow: FSISI “Rosinformagrotekh" Publ., 2019. (In Russian)]

Дорофеев В.Ф. Морфолого-анатомическое исследование вегетативных органов культурных представителей рода Brassica L.: ABтореф. дис. ... канд. биол. наук. М.: МСXА, 1955.

[Dorofeev V.F. Morphologo-Anatomical Investigations into Vegetative Organs of Cultivated Representatives of the Genus Brassica L. PhD (Agric.) Thesis. Moscow: Timiryazev Agricultural Academy Publ., 1955. (in Russian)]

Дорофеев В.Ф. Морфолого-анатомическое исследование вегетативных органов культурных представителей рода Brassica L. Tp. по прикл. ботанике, генетике и селекции. 1957;31(2):150-169. [Dorofeev V.F. Morphologo-anatomical investigations into vegetative organs of cultivated representatives of the genus Brassica L. Trudy po Prikladnoy Botanike, Genetike i Selektsii = Proceedings on Applied Botany, Genetics and Breeding. 1957;31(2):150-169. (in Russian)]

Дорофеев В.Ф. Роль придаточных корней в устойчивости пшеницы против полегания. Селекция и семеноводство. 1959;4:70-72. [Dorofeev V.F. The role of the accessory roots for wheat resistance to lodging. Selektsiya i Semenovodstvo. 1959;4:70-72. (in Russian)]

Дорофеев В.Ф. Некоторые данные исследования полегания пшениц. Тр. по прикл. ботанике, генетике и селекции. 1960;32(2):293-306. [Dorofeev V.F. Some data on the study of wheat lodging. Trudy po Prikladnoy Botanike, Genetike i Selektsii = Proceedings on Applied Botany, Genetics and Breeding. 1960;32(2):293-306. (in Russian)]

Дорофеев В.Ф. Анатомическое строение стебля некоторых видов пшеницы и его связь с полеганием. Ботан. журнал. 1962;47(3): 374-380.

[Dorofeev V.F. The anatomical structure of the stem of a some wheat species and its relationship with lodging. Botanicheskiy Jurnal = Botanical Journal. 1962;47(3):374-380. (in Russian)]

Дорофеев В.Ф. Географическая локализация и генцентры гексаплоидных пшениц в Закавказье. Генетика. 1966;3:16-33.

[Dorofeev V.F. Geographical localization and gene centers of hexaploid wheat in the Transcaucasia. Genetika = Genetics (Moscow) 1966;3:16-33. (in Russian)]

Дорофеев В.Ф. Новые ботанические формы твердой пшеницы. С.-х. биология. 1968a;111(3):345-349.

[Dorofeev V.F. New botanical forms of durum wheat. Selskokhozyay- stvennaya Biologiya = Agricultural Biology. 1968a;111(3):345-349. (in Russian)]

Дорофеев В.Ф. Спонтанные мутации как фактор формообразования пшеницы. Генетика. 19686;4(3):72-83.

[Dorofeev V.F. Spontaneous mutations as a factor in the wheat morphogenesis. Genetika = Genetics (Moscow). 1968b;4(3):72-83. (in Russian)]

Дорофеев В.Ф. Полиморфизм пшениц Грузии. Тр. по прикл. ботанике, генетике и селекции. 1969а;39(3):91-134

[Dorofeev V.F. Polymorphism of Georgian wheats. Trudy po Prikladnoy Botanike, Genetike i Selektsii = Proceedings on Applied Botany, Genetics and Breeding. 1969a;39(3):91-134. (in Russian)]

Дорофеев В.Ф. Идеи Н.И. Вавилова в современных исследованиях рода Triticum L. B: Н.И. Вавилов и сельскохозяйственная наука. М.: Колос, 19696;262-286.

[Dorofeev V.F. N.I. Vavilov's ideas in modern studies of the genus Triticum L. In: N.I. Vavilov and Agricultural Science. Moscow: Kolos Publ., 1969b;262-286. (in Russian)]

Дорофеев В.Ф. Ботанический потенциал пшениц Закавказья. Тр. по прикл. ботанике, генетике и селекции. 1970а;42(2):122-149.

[Dorofeev V.F. Botanical potential of Transcaucasian wheat. Trudy po Prikladnoy Botanike, Genetike i Selektsii = Proceedings on Applied Botany, Genetics and Breeding. 1970a;42(2):122-149. (in Russian)]

Дорофеев В.Ф. Новые разновидности спельты (Trilicum spelta L.) Закавказья. Тр. по прикл. ботанике, генетике и селекции. 1970б; 42(2):282-297.

[Dorofeev V.F. New botanical varieties of spelt (Trilicum spelta L.). Trudy po Prikladnoy Botanike, Genetike i Selektsii = Proceedings on Applied Botany, Genetics and Breeding. 1970b;42(2):282-297. (in Russian)]

Дорофеев В.Ф. Новые формы твердой пшеницы (Trilicum durum Desf.) Закавказья с ветвистым колосом. Тр. по прикл. ботанике, генетике и селекции. 1971а;43(1):306-308.

[Dorofeev V.F. New forms of Transcaucasian durum wheat (Trilicum durum Desf.) with a branch spike. Trudy po Prikladnoy Botanike, Genetike $i$ Selektsii $=$ Proceedings on Applied Botany, Genetics and Breeding. 1971a;43(1):306-308. (in Russian)]

Дорофеев В.Ф. Ботанический состав и селекционное значение спельт Закавказья. Вестн. с.-х. науки. 19716;7:44-56.

[Dorofeev V.F. Botanical composition and breeding value of Transcaucasian spelt. Vestnik Selskokhozyaystvennoy Nauki = Bulletin of Agricultural Science. 1971b;7:44-56. (in Russian)]

Дорофеев В.Ф. Ботанический состав и селекционное значение пшениц Закавказья: Автореф. дис. ... д-ра с.-х. наук. Л.: ВИР, 1971 в. [Dorofeev V.F. Botanical Composition and Breeding Value of the Wheat in the Transcaucasus. Dr. Sci. (Agric.) Thesis. Leningrad: VIR Publ., 1971c. (in Russian)]

Дорофеев В.Ф. Зерновые культуры Индии. Тр. по прикл. ботанике, генетике и селекции. 1971г;45(2):159-182.

[Dorofeev V.F. Cereals of India. Trudy po Prikladnoy Botanike, Genetike $i$ Selektsii = Proceedings on Applied Botany, Genetics and Breeding. 1971d;45(2):159-182. (in Russian)]

Дорофеев В.Ф. Пшеницы Закавказья: ботанический состав, эволюция и роль в селекции. Тр. по прикл. ботанике, генетике и селекции. 1972;47(1):3-202.

[Dorofeev V.F. Transcaucasia Wheat: botanical composition, evolution, and role in breeding. Trudy po Prikladnoy Botanike, Genetike i Selektsii $=$ Proceedings on Applied Botany, Genetics and Breeding. 1972;47(1):3-202. (in Russian)]

Дорофеев В.Ф. Селекционный фонд карликовых и короткостебельных сортов пшеницы. В: Селекция короткостебельных пшениц. М.: Колос, 1975:28-38.

[Dorofeev V.F. Breeding fund for dwarf and short-straw wheat varieties. In: Breeding of Short-straw Wheat. Moscow: Kolos Publ., 1975:2838. (in Russian)]

Дорофеев В.Ф. Закавказье как первичный центр происхождения и активный современный очаг формообразования пшеницы. В: Закавказский симпозиум по биологии пшеницы (12-13 октября 1976 г.): тез. докл. Эчмиадзин, 1976а:10-12.

[Dorofeev V.F. Transcaucasia as the primary center of origin and an active modern center of wheat formation. In: Transcaucasian Symposium on Wheat Biology (October 12-13, 1976): Abstracts. Echmiadzin, 1976a:10-12. (in Russian)]

Дорофеев В.Ф. Мировая коллекция тритикале как основа получения перспективных сортов. В: Тритикале: Проблемы и перспек- 
тивы. Ч. 1. Генетика и селекция тритикале. Каменная степь, 19766 $17-24$.

[Dorofeev V.F. World Triticale collection as the basis for promising cultivars. In: Triticale: Probleme and Perspectives. Part 1. Genetics and Breeding of Triticale. Kamennaya Step, 1976b:17-24. (in Russian)]

Дорофеев В.Ф. Развитие идей Н.И. Вавилова в современных исследованиях. Вестн. с.-х. науки. 1979;1:15-22.

[Dorofeev V.F. The development of N.I. Vavilov's ideas in modern research. Vestnik Selskokhozyaystvennoy Nauki = Bulletin of Agricultural Science. 1979;11:15-22. (in Russian)]

Дорофеев В.Ф. Н.И. Вавилов - основоположник учения об исходном материале. Вестн. с.-х. науки. 1980а;3:52-55

[Dorofeev V.F. N.I. Vavilov - a founder of the study on pre-breeding material. Vestnik Selskokhozyaystvennoy Nauki = Bulletin of Agricultural Science. 1980a;3:52-55. (in Russian)]

Дорофеев В.Ф. Профессор Константин Андреевич Фляксбергер: к 100-летию со дня рождения. Тр. по прикл. ботанике, генетике и селекции. 19806;68(1):1-2

[Dorofeev V.F. Professor Konstantin Andreevich Flyaksberger: the 100th anniversary of his birth. Trudy po Prikladnoy Botanike, Gene tike i Selektsii = Proceedings on Applied Botany, Genetics and Breeding. 1980b;68(1):1-2. (in Russian)]

Дорофеев В.Ф. Учение Н.И. Вавилова о виде как системе и его дальнейшее развитие. С.-х. биология. 1980в;3:323-333.

[Dorofeev V.F. N.I. Vavilov doctrine about the species as a system and its further development. Selskokhozyaystvennaya Biologiya = Agricultural Biology. 1980c;3:323-333. (in Russian)]

Дорофеев В.Ф. Бюро профессора Регеля. Нева. 1985а;4:196-202. [Dorofeev V.F. Professor Regel's Bureau. Neva. 1985a;4:196-202. (in Russian)]

Дорофеев В.Ф. У истоков высоких урожаев. Л.: Лениздат, 19856. [Dorofeev V.F. At the Cradle of High Yields. Leningrad: Lenizdat Publ. 1985b. (in Russian)]

Дорофеев В.Ф. Теория центров происхождения культурных растений Н.И. Вавилова и ее развитие. Вестн. С.-х. науки. 1986;1:55-66. [Dorofeev V.F. N.I. Vavilov's theory of centers of origin of cultivated plants and its development. Vestnik Selskokhozyaystvennoy Nauki = Bulletin of Agricultural Science. 1986;1:55-66. (in Russian)]

Дорофеев В.Ф., Агафонов Н.П. Растениеводство и постановка опытной работы в Сомали, Кении и Бурунди. Тр. по прикл. ботанике, генетике и селекции. 1973;49(1):260-271.

[Dorofeev V.F., Agafonov N.P. Crop production and experimental work in Somalia, Kenya and Burundi. Trudy po Prikladnoy Botanike, Genetike $i$ Selektsii $=$ Proceedings on Applied Botany, Genetics and Breeding. 1973;49(1):260-271. (in Russian)]

Дорофеев В.Ф., Атланов А.В. Растениеводство Сирии и Ирака. В: Ми ровые растительные ресурсы в Средней Азии. Сб. трудов Среднеазиатского филиала ВИР. Ташкент, 1981;8:3-21.

[Dorofeev V.F., Atlanov A.V. Plant industry of Syria and Iraq. In: World Plant Resources in Central Asia. Proc. Central Asian Branch of VIR. Tashkent, 1981;8:3-21. (in Russian)]

Дорофеев В.Ф., Берлянд-Кожевников В.М. Некоторые особенности эволюции культурных видов пшеницы. С.-х. биология. 1977;12(6) 860-868.

[Dorofeev V.F., Berlyand-Kozhevnikov V.M. Some features of the evolution of cultivated wheat species. Selskokhozyaystvennaya Biologiya = Agricultural Biology. 1977;12(6):860-868. (in Russian)]

Дорофеев В.Ф., Градчанинова О.Д. Анатомическое изучение стебля и листа пшеницы. Тр. по прикл. ботанике, генетике и селекции. 1971;44(1):57-75.

[Dorofeev V.F., Gradchaninova O.D. Anatomical study of wheat stem and leaf. Trudy po Prikladnoy Botanike, Genetike $i$ Selektsii $=$ Proceedings on Applied Botany, Genetics and Breeding. 1971;44(1):57-75. (in Russian)]

Дорофеев В.Ф., Корсаков Н.И. Полевые культуры Пакистана. Тр. по прикл. ботанике, генетике и селекции. 1973;49(1):211-235.

[Dorofeev V.F., Korsakov N.I. Pakistan field crops. Trudy po Prikladnoy Botanike, Genetike i Selektsii = Proceedings on Applied Botany, Genetics and Breeding. 1973;49(1):211-235. (in Russian)]

Дорофеев В.Ф., Куркиев У.К. Мировая коллекция тритикале и использование ее в селекции. В: Тритикале: изучение и селекция Матер. междунар. симпозиума. (Ленинград, 3-7 июля 1973 г.). Л.: BИР, 1975:12-25.
[Dorofeev V.F., Kurkiev U.K. World collection of Triticale and its use in breeding. In: Triticale: Study and Breeding: Mater. Intern. Symp. (Leningrad, July 3-7, 1973). Leningrad: VIR Publ., 1975:12-25. (in Russian)]

Дорофеев В.Ф., Куркиев У.К. Методы получения и улучшения тритикале. Тр. по прикл. ботанике, генетике и селекции. 1977;60(1): 119-123.

[Dorofeev V.F., Kurkiev U.K. Methods for creating and improving Triticale. Trudy po Prikladnoy Botanike, Genetike $i$ Selektsii = Proceedings on Applied Botany, Genetics and Breeding. 1977;60(1):119-123. (in Russian)]

Дорофеев В.Ф., Мережко А.Ф. Пшеницы Закавказья для селекции на устойчивость к бурой ржавчине в условиях Кубани. Тр. по прикл. ботанике, генетике и селекции. 1971;43(3):27-33.

[Dorofeev V.F., Merezhko A.F. Wheat of Transcaucasia for breeding for resistance to brown rust in environments of Kuban. Trudy po Prikladnoy Botanike, Genetike i Selektsii = Proceedings on Applied Botany, Genetics and Breeding. 1971;43(3):27-33. (in Russian)]

Дорофеев В.Ф., Мигушова Э.Ф. Ботаническое разнообразие эгилопсов (Aegilops L.) Закавказья. Тр. по прикл. ботанике, генетике и селекции. 1966;38(2):152-158.

[Dorofeev V.F., Migushova E.F. Botanical diversity of goat grass (Aegilops L.) from the Transcaucasus. Trudy po Prikladnoy Botanike, Genetike $i$ Selektsii $=$ Proceedings on Applied Botany, Genetics and Breeding. 1966;38(2):152-158. (in Russian)]

Дорофеев В.Ф., Мигушова Э.Ф. Новый вид пшеницы Triticum kiharae Dorof. et Migusch., гомолог спельты. Бюл. ВИР. 1977;71:83.

[Dorofeev V.F., Migushova E.F. A new species of wheat Triticum kiharae Dorof. et Migusch., the homologue of spelt. Bulleten VIR $=$ VIR Bulletin. 1977;71:83. (in Russian)]

Дорофеев В.Ф., Мигушова Э.Ф. Вклад К.А. Фляксбергера в изучение филогении пшеницы и современное понимание ее происхождения. Бюл. ВИР. 1981a;106:23-26.

[Dorofeev V.F., Migushova E.F. K.A. Flaksberger's contribution to study of the phylogeny of wheat and a modern understanding of its origin. Bulleten VIR = VIR Bulletin. 1981a;106:23-26. (in Russian)]

Дорофеев В.Ф., Мигушова Э.Ф. Новое в эволюции и систематике пшеницы. Докл. ВАСХНИЛ. 19816;2:6-9.

[Dorofeev V.F., Migushova E.F. New in the evolution and taxonomy of wheat. Doklady VASHNIL = USSR Academy of Agriculture's Reports. 1981b;2:6-9. (in Russian)]

Дорофеев В.Ф., Пономарев В.И. Проблема полегания пшеницы и пути ее решения. М., 1970.

[Dorofeev V.F., Ponomarev V.I. The Problem of Wheat Lodging and Ways to its Solve. Moscow, 1970. (in Russian)]

Дорофеев В.Ф., Сурганова Л.Д. Неполегающие образцы пшеницы как исходный материал для селекции на орошении. Тр. по прикл. ботанике, генетике и селекции. 1970;41(3):121-124.

[Dorofeev V.F., Surganova L.D. No-lodging wheat accessions as starting material for breeding for irrigation. Trudy po Prikladnoy Botanike, Genetike $i$ Selektsii = Proceedings on Applied Botany, Genetics and Breeding. 1970;41(3):121-124. (in Russian)]

Дорофеев В.Ф., Филатенко А.А. Становление и развитие учения Н.И. Вавилова о центрах происхождения культурных растений. Генетика. 1987;11:1916-1926.

[Dorofeev V.F., Filatenko A.A. Formation and development of the N.I. Vavilov doctrine about the centers of cultivated plants origin. $\mathrm{Ge}$ netika = Genetics (Moscow). 1987;11:1916-1926. (in Russian)]

Дорофеев В.Ф., Ядров А.А. Некоторые особенности сельского хозяйства Бангладеш. Сел. хоз-во за рубежом. 1981;2:21-23.

[Dorofeev V.F., Yadrov A.A. Some features of Bangladesh's agriculture. Selskoye Khozyaystvo za Rubezhom = Agriculture Abroad. 1981;2: 21-23. (in Russian)]

Дорофеев В.Ф., Куркиев У.К., Филатенко А.А., Охотникова Т.В. Мировая коллекция тритикале как основа получения перспективных сортов. Тр. по прикл. ботанике, генетике и селекции. 1977;59(3): 24-30.

[Dorofeev V.F., Kurkiev U.K., Filatenko A.A., Okhotnikova T.V. World Triticale collection as the basis for promising cultivars. Trudy po Prikladnoy Botanike, Genetike i Selektsii = Proceedings on Applied Botany, Genetics and Breeding. 1977;59(3):24-30. (in Russian)]

Дорофеев В.Ф., Мельников А.Ф., Семенова Л.В. Образцы яровой 
пшеницы, ценные для селекции в Куйбышевской области. Тр. по прикл. ботанике, генетике и селекции. 1976;58(2):19-24.

[Dorofeev V.F., Melnikov A.F., Semenova L.V. Spring wheat accessions valuable for breeding in the Kuibyshev region. Trudy po Prikladnoy Botanike, Genetike i Selektsii = Proceedings on Applied Botany, Genetics and Breeding. 1976;58(2):19-24. (in Russian)]

Дорофеев В.Ф., Мигушова Э.Ф., Берштейн Э.М. Ботанический состав эгилопсов Кавказа в сборах экспедиций ВИР. Тр. по прикл. бота нике, генетике и селекции. 1969;40(2):118-125.

[Dorofeev V.F., Migushova E.F., Bershtein E.M. The botanical composition of the Aegilops of the Caucasus collected by VIR expeditions. Trudy po Prikladnoy Botanike, Genetike i Selektsii = Proceedings on Applied Botany, Genetics and Breeding. 1969;40(2):118-125. (in Russian)]

Дорофеев В.Ф., Новикова М.В., Градчанинова О.Д. и др. Зимостойкие пшеницы (методические указания). Л.: ВИР, 1973а.

[Dorofeev V.F., Novikova M.V., Gradchaninova O.D. et al. Winter-resis tant Wheat. Guidelines. Leningrad: VIR Publ., 1973a. (in Russian)]

Дорофеев В.Ф., Охотникова Т.В., Мигушова Э.Ф. Межродовая гибридизация пшеницы, ржи, эгилопса и проблема классификации тритикале. Тр. по прикл. ботанике, генетике и селекции. 1982 73(3):3-8.

[Dorofeev V.F., Okhotnikova T.V., Migushova E.F. Intergeneric hybridization of wheat, rye and goat grass and the problem of classification triticale. Trudy po Prikladnoy Botanike, Genetike $i$ Selektsii $=$ Pro ceedings on Applied Botany, Genetics and Breeding. 1982;73(3):3-8. (in Russian)]

Дорофеев В.Ф., Руденко М.И., Удачин Р.А. Селекционный фонд кар ликовых и короткостебельных сортов яровой и озимой пшеницы. Тр. по прикл. ботанике, генетике и селекции. 19736;49(3) 72-80.

[Dorofeev V.F., Rudenko M.I., Udachin R.A. Breeding fund for dwarf and short-straw varieties of spring and winter wheat. Trudy po Prikladnoy Botanike, Genetike i Selektsii = Proceedings on Applied Botany, Genetics and Breeding. 1973b;49(3):72-80. (in Russian)]

Дорофеев В.Ф., Руденко М.И., Удачин Р.А. и др. Засухоустойчивые пшеницы: методические указания. Л.: ВИР, 1974.

[Dorofeev V.F., Rudenko M.I., Udachin R.A. et al. Drought Resistant Wheat: Guidelines. Leningrad: VIR Publ., 1974. (in Russian)]

Дорофеев В.Ф., Руденко М.И., Удачин Р.А., Якубцинер М.М. Селекция короткостебельных сортов пшеницы: (Методическое пособие). Л.: ВИР, 1970.

[Dorofeev V.F., Rudenko M.I., Udachin R.A., Yakubtsiner M.M. Breeding of Short Dwarf of Wheat: (Guidelines). Leningrad: VIR Publ., 1970. (in Russian)]

Дорофеев В.Ф., Саранин К.И., Степанов А.И. Пшеница в Нечерноземье. Л.: Колос, 1983.

[Dorofeev V.F., Saranin K.I., Stepanov A.I. Wheat in the No-Chernozem Region. Leningrad: Kolos Publ., 1983. (in Russian)]

Дорофеев В.Ф., Филатенко А.А., Мигушова Э.Ф., Удачин Р.А., Якубци нер М.М. Культурная флора СССР. Т. 1. Пшеница. Л.: Колос, 1979. [Dorofeev V.F., Filatenko A.A., Migushova E.F., Udachin R.A., Yakubtsiner M.M. Flora of Cultivated Plants of USSR. Vol. 1. Wheat. Leningrad: Kolos Publ., 1979. (in Russian)]

Дорофеев В.Ф., Филатенко А.А., Удачин Р.А. Н.И. Вавилов и современная тритикология. Тр. по прикл. ботанике, генетике и селекции. 1987;100:9-20.

[Dorofeev V.F., Filatenko A.A., Udachin R.A. N.I. Vavilov and modern triticology. Trudy po Prikladnoy Botanike, Genetike i Selektsii = Proceed ings on Applied Botany, Genetics and Breeding. 1987;100:9-20. (in Russian)]

Звейнек И.А. Выбор тестеров для генетической оценки сортов яровой мягкой пшеницы по высоте растений. Бюл. ВИР. 1984;144: 9-10.

[Zveinek I.A. Choice of standarts for the genetic evaluation of spring wheat cultivars for plant height. Bulleten VIR = VIR Bulletin. 1984;144 9-10. (in Russian)]

Зуев Е.В., Амри А., Брыкова А.Н., Пюккенен В.П., Митрофанова О.П. Атлас разнообразия мягкой пшеницы (Triticum aestivum L.) по признакам колоса и зерновки. 2-е изд. СПб.: Копи-Р, 2019.

[Zuev E.V., Amri A., Brykova A.N., Pyukkenen V.P., Mitrofanova O.P. Atlas of bread wheat (Triticum aestivum L.) genetic diversity based on spike and kernel characters. 2nd ed. St. Petersburg: Kopi-R Publ., 2019. (in Russian)]
Конарев А.В., Гаврилюк И.П., Мигушова Э.Ф. Дифференциация диплоидных пшениц по данным иммунохимического анализа глиадина. Докл. ВАСХНИЛ. 1974(6):12-14.

[Konarev A.V., Gavrilyuk I.P., Migushova E.F. Differentiation of diploid wheat according immunochemical analysis of gliadin. Doklady VASKhNIL $=$ Reports of the Academy of Agricultural Sciences. 1974(6): 12-14. (in Russian)]

Конарев В.Г. Белки пшеницы. М.: Колос, 1980.

[Konarev V.G. Wheat Proteins. Moscow: Kolos Publ., 1980. (in Russian)]

Конарев В.Г. Белки растений как генетические маркеры. М.: Колос, 1983.

[Konarev V.G. Plant Proteins as Genetic Markers. Moscow: Kolos Publ., 1983. (in Russian)]

Конарев В.Г., Гаврилюк И.П., Пенева Т.И., Конарев А.В., Хакимова А.Г. Мигушова Э.Ф. О природе и происхождении геномов пшеницы по данным биохимии и иммунохимии белков зерна. С.-х. биология. 1976;11(5):656-665.

[Konarev V.G., Gavrilyuk I.P., Peneva T.I., Konarev A.V., Khakimova A.G., Migushova E.F. About the nature and origin of wheat genomes according the data of biochemistry and immunochemistry of grain proteins. Selskokhozyaystvennaya Biologiya = Agricultural Biology. 1976;11(5):656-665. (in Russian)]

Конарев В.Г., Дорофеев В.Ф., Мигушова Э.Ф., Филатенко А.А. Геномный состав и система рода Triticum L. Tp. по прикл. ботанике, генетике и селекции. 1978;63(2):6-14.

[Konarev V.G., Dorofeev V.F., Migushova E.F., Filatenko A.A. Genomes and system of the genus Triticum L. Trudy po Prikladnoy Botanike, Genetike i Selektsii = Proceedings on Applied Botany, Genetics and Breeding. 1978;63(2):6-14. (in Russian)]

Куркиев К.У., Тырышкин Л.Г., Колесова М.А., Куркиев У.К. Идентификация генов короткостебельности Rht2 и Rht8 у образцов гексаплоидного тритикале с помощью ДНК маркеров. Вавиловский журнал генетики и селекции. 2008;12(3):372-377.

[Kurkiev K.U., Tyryshkin L.G., Kolesova M.A., Kurkiev U.K. Identification of Rht2 and Rht8 dwarwing genes in hexaploid Triticale accessions using DNA markers. Vavilovskii Zhournal Genetiki $i$ Selektsii = Vavilov Journal of Genetics and Breeding. 2008;12(3):372-377. (in Russian)]

Левитский Г.А., Бенецкая Г.К. Цитология пшенично-ржаных амфиди плоидов. Тр. по прикл.ботанике, генетике и селекции. 1931;27: 241-264.

[Levitsky G.A., Benetskaya G.K. Cytology of wheat-rye amphidiploids. Trudy po Prikladnoy Botanike, Genetike i Selektsii = Proceedings on Applied Botany, Genetics and Breeding. 1931;27:241-264. (in Russian)]

Лобанов П.П., Брежнев Д.Д., Дорофеев В.Ф., Трофимовская А.Я. Выдающийся ученый-биолог: к 90-летию со дня рождения академика Петра Михайловича Жуковского. Вестн. с.-х. науки. 1978;4 142-147.

[Lobanov P.P., Brezhnev D.D., Dorofeev V.F., Trofimovskaya A.Ya. Famous biologist: on the 90th anniversary of the birth of Peter Mikhailovich Zhukovsky. Vestnik Selskokhozyaystvennoy Nauki = Bulletin of Agricultural Science. 1978;4:142-147. (in Russian)]

Лоскутова Н.П. Гены короткостебельности пшеницы. Аграр. Россия. 2002;1:25-30.

[Loskutova N.P. Dwarfing genes in wheat. Agrarnaya Russia = Agrarian Russia. 2002;1:25-30. (in Russian)]

Лукьяненко П.П. Селекция высокоурожайных низкостебельных сортов озимой пшеницы. С.-х. биология. 1969;4(4):483-492.

[Lukyanenko P.P. Breeding of high-yielding short-straw cultivars of winter wheat Selskokhozyaystvennaya Biologiya = Agricultural Biology. 1969;4(4):483-492. (in Russian)]

Ляпунова О.А. Селекция твердой пшеницы в Италии. Письма в Вавиловский журнал генетики и селекции. 2019;5(1):19-34. DOI 10.18699/Letters2019-5-3.

[Lyapunova O.A. Durum wheat breeding in Italy. Pisma $v$ Vavilovski Zhurnal Genetiki i Selektsii = Letters to Vavilov Journal of Genetics and Breeding. 2019;5(1):19-34. DOI 10.18699/Letters2019-5-3. (in Russian)]

Менабде В.Л. Пшеницы Грузии. Тбилиси: Изд-во АН Грузии, 1948. [Menabde V.L. Wheat of Georgia. Tbilisi: Publ. House of the Georgian Acad. Sci., 1948. (In Russian)]

Мережко А.Ф. Классификация. В: Генетика культурных растений. 
Зерновые культуры. Гл. 1. Генетика пшеницы. Л.: Агропромиздат, 1986.

[Merezhko A.F. Classification. In: Genetics of Cultivated Plants. Crops Chapter 1. Genetics of Wheat. Leningrad: Agropromizdat Publ., 1986. (in Russian)]

Мережко А.Ф. Наследование высоты растений во внутривидовых скрещиваниях мягкой пшеницы. Тр. по прикл. ботанике, генети ке и селекции. 1991;142:53-58.

[Merezhko A.F. Inheritance of plant height in an intraspecific hybridization in common wheat. Trudy po Prikladnoy Botanike, Genetike i Selektsii = Proceedings on Applied Botany, Genetics and Breeding. 1991;142:53-58. (in Russian)]

Мережко А.Ф., Градчанинова О.Д. Наследование длины соломины и анатомического строения стебля межсортовыми гибридами мягкой пшеницы. Бюл. ВИР. 1982;122:18-22.

[Merezhko A.F., Gradchaninova O.D. Inheritance of the straw length and the anatomical structure of the stem by intervaretal hybrids of common wheat. Bulleten VIR = VIR Bulletin. 1982;122:18-22. (in Russian)]

Мережко А.Ф., Писарева Л.А., Прилюк Л.В. Генетический контроль высоты растения у пшеницы. Генетика. 1986;22(5):725-732.

[Merezhko A.F., Pisareva L.A., Priluk L.V. Genetic control of plant height in wheat. Genetika = Genetics (Moscow). 1986;22(5):725-732. (in Russian)]

Мережко А.Ф., Удачин Р.А., Зуев В.Е., Филатенко А.А., Сербин А.А., Ляпунова О.А., Косов В.Ю., Куркиев У.К., Охотникова Т.В., Навруз беков Н.А., Богуславский Р.Л., Абдулаева А.К., Чикида Н.Н., Митрофанова О.П., Потокина С.А. Методические указания. Пополнение, сохранение в живом виде и изучение мировой коллекции пшеницы, эгилопса и тритикале. СПб.: ВИР, 1999.

[Merezhko A.F., Udachin R.A., Zuev V.E., Filatenko A.A., Serbin A.A. Lyapunova O.A., Kosov V.Yu., Kurkiev U.K., Okhotnikova T.V., Navruzbekov N.A., Boguslavsky R.L., Abdulaeva A.K., Chikida N.N., Mitrofanova O.P., Potokina S.A. Methodical Instructions. Replenishment, Preservation in a Living Form and Study of World Collection of Wheat Goat Grass and Triticale. St. Petersburg: VIR Publ., 1999. (in Russian)]

Пшеницы мира. Л.: Колос, 1976.

[Wheat of the World. Leningrad: Kolos Publ., 1976. (in Russian)]

Пшеницы мира. 2-е изд., перераб. и доп. Л.: Агропромиздат, 1987.

[Wheat of the World. 2nd ed. Leningrad: Agropromizdat Publ., 1987. (in Russian)]

Соратники Николая Ивановича Вавилова: исследователи генофонда растений. 2-е изд., знач. перераб. и доп. СПб.: ВИР, 2017. [Associates of Nikolai Ivanovich Vavilov: Researchers of the Plant Gene Pool. 2nd ed. St. Petersburg: VIR Publ., 2017. (in Russian)]

Удачин Р.А., Мигушова Э.Ф. Новое в познании рода Triticum. Becmн. с.-х. науки. 1970;9:20-24.

[Udachin R.A., Migushova E.F. New in the cognition of the genus Triticum. Vestnik Selskokhozyaystvennoy Nauki = Bulletin of Agricultural Science. 1970;9:20-24. (in Russian)]

Удачин Р.А., Шахмедов И.Ш. Новый ветвистоколосный подвид пшеницы T. turgidum L. ssp. jakubzineri Udacz. et Schachm. Бюл. ВИР. 1972;23:3-4.

[Udachin R.A., Schachmedov I.Sh. A new branch-spike subspecies of wheat T. turgidum L. ssp. jakubzineri Udacz. et Schachm. Bulleten VIR = VIR Bulletin. 1972;23:3-4. (in Russian)]

Уколов А.А., Хупацария Т.И., Рубец В.С., Соловьев А.А. Определитель зерновых, зернобобовых культур и кормовых трав. М.: ФГОУ ВПО РГАУ-МСХА им. К.А. Тимирязева, 2006;19-20.

[Ukolov A.A., Khupatsaria T.I., Rubets V.S., Soloviev A.A. Manual book of cereals, legumes and forage grasses. M.: RGAU-Timiryazev MAA Publ., 2006;19-20.]

Филатенко А.А., Куркиев У.К. Пшеница Синской (Новый вид - Triticum sinskajae A. Filat. et Kurk.). Тр. по прикл. ботанике, генетике и селекции. 1975;54(1):239-241.

[Filatenko A.A., Kurkiev U.K. Sinskaya Wheat (New species - Triticum sinskajae A. Filat. et Kurk.). Trudy po Prikladnoy Botanike, Genetike i Selektsii = Proceedings on Applied Botany, Genetics and Breeding. 1975; 54(1):239-241.

Чеботарь Г.А., Чеботарь С.В., Моцный И.И. Плейотропные эффекты гиббереллинчувствительных и нечувствительных генов короткостебельности мягкой пшеницы в условиях Причерноморья. Цитология и генетика. 2016;50(1):26-35. DOI 10.3103/S00954527 16010023.
[Chebotar G.A., Chebotar S.V., Motsnyy I.I. Pleiotropic effects of gibberellin-sensitive and giberrellin-insensitive dwarfing genes in bread wheat of the southern step region of the Black Sea. Cytologiya i Genetika = Cytology and Genetics. 2016;50(1):20-27. DOI 10.3103/ S0095452716010023. (in Ukrainian)]

Чухина И.Г. Номенклатурные типы таксонов, названных в честь Н.И. Вавилова, в гербарной коллекции ВИР (WIR). Vavilovia. 2019; 2(1):3-11. DOI 10.30901/2658-3860-2019-1-3-11.

[Chukhina I.G. Nomenclatural types of the taxa named after N.I. Vavilov in the herbarium collection of VIR (WIR). Vavilovia. 2019;2(1): 3-11. DOI 10.30901/2658-3860-2019-1-3-11. (in Russian)]

Шумный В.К., Гончаров П.Л. Памяти академика РАСХН Анатолия Васильевича Пухальского (16.07.1909-28.02.2008). Информачионный вестник ВОГИС. 2008;12(1-2):262-267.

[Shumny V.K., Goncharov P.L. In memoriam: Academician of the Russian Academy of Agricultural Sciences Anatoliy V. Pukhalskiy (July 16, 1909 - February 28, 2008). The Herald of Vavilov Society for Geneticists and Breeding Scientists. 2008;12(1-2):262-267. (in Russian)]

Щербаков Ю.Н. Экспедиции института по СССР и в зарубежные страны. Тр. по прикл. ботанике, генетике и селекции. 1969;40(2):3-19. [Shcherbakov Yu.N. Expedition of the Institute in the USSR and in foreign countries. Trudy po Prikladnoy Botanike, Genetike $i$ Selektsii = Proceedings on Applied Botany, Genetics and Breeding. 1969;40(2): 3-19. (in Russian)]

Щербаков Ю.Н., Чикова В.А. Зарубежные экспедиции ВИРа по сбору растительных ресурсов. Тр. по прикл. ботанике, генетике и селекции. 1970;42(2):316-320.

[Shcherbakov Yu.N., Chikova V.A. VIR's foreign expeditions to collect plant resources. Trudy po Prikladnoy Botanike, Genetike $i$ Selektsii $=$ Proceedings on Applied Botany, Genetics and Breeding. 1970;42(2): 316-320. (in Russian)]

Щербаков Ю.Н., Чикова В.А. Экспедиции Института по СССР. Тр. по прикл. ботанике, генетике и селекции. 1971;45(2):299-320.

[Shcherbakov Yu.N., Chikova V.A. Expeditions of the Institute in the USSR. Trudy po Prikladnoy Botanike, Genetike i Selektsii = Proceedings on Applied Botany, Genetics and Breeding. 1971;45(2):299-320. (in Russian)]

Янченко В.И. Хозяйственно-биологическая оценка мировой коллекции полбы Triticum dicoccum (Schrank) Schuebl. в Алтайском крае и ее использование в селекции яровой пшеницы: Автореф. дис. ... канд. с.-х. наук. Л., 1983.

[Yanchenko V.I. Economic and biological assessment of the world collection of emmer Triticum dicoccum (Schrank) Schuebl. in the Altai territory and its use in the breeding of spring wheat: $\mathrm{PhD}$ (Agric.) Thesis. Leningrad, 1983. (in Russian)]

Bhatta M., Shamanin V., Shepelev S., Baenziger P.S., Pozherukova V., Pototskaya I., Morgounov A. Marker-trait associations for enhancing agronomic performance, disease resistance, and grain quality in synthetic and bread wheat accessions in Western Siberia. G3: Genes, Genomes, Genetics. 2019;9(12):4209-4222. DOI 10.1534/g3.119.400811.

Borlaug N. Wheat breeding and its impact on world food supply. Proc. 3rd Int. Wheat Genetics Symposium. Canberra: Austr. Acad. Sci. 1968:1-36.

Dorofeev V.F. The variability and breeding value of Armenian wheats. Euphytica. 1968;17(3):451-461. DOI 10.1007/BF00056247.

Dorofeev V.F. Die Weizen Transkaukasiens und ihre bedeutung in der evolution der gattung Triticum L. 1. Die Formenmannigfaltigkeit der Weizen Transkaukasiens. Z. Pflanzenzücht. 1969a;61(1):1-28.

Dorofeev V.F. Die Weizen Transkaukasiens und ihre Bedeutung in der Evolution der Gattung Triticum L. 2. Die Formenbildung in Populationen der Weizen Transkaukasiens. Z. Pflanzenzücht. 1969b;62(3): 201-230.

Dorofeev V.F. Spontaneous hybridization in wheat populations of Transcaucasia. Euphytica. 1969c;18(3):406-416. DOI 10.1007/BF00397790.

Dorofeev V.F. Die Weizen Transkaukasiens und ihre kuckuckianum Gorg. und ssp. vavilovii SearsBedeutung in der Evolution der Gattung Triticum L. 3. Die Spelzweizen Transkaukasiens (T. macha Dek. et Men., T. spelta L. ssp. spelta Dorof., ssp. kuckuckianum Gorg. und ssp. vavilovii Sears). Z. Pflanzenzücht. 1971;66(4):335-360.

Dorofeev V.F., Miguschowa E.F. Evolution und Klassifikation der Gattung Triticum L. 1. Mitt. Die Abstammung des polyploiden Weizens. Arch. Züchtungsforsch. 1983a;13(5):299-312.

Dorofeev V.F., Miguschowa E.F. Evolution und Klassifikation der Gattung 
Triticum L. 2. Mitt. Das System der Gattung Triticum L. Arch. Züchtungsforsch. 1983b;13(6):377-385.

Dvořák J., Terlizzi P.D., Zhang H.B., Resta P. The evolution of polyploid wheats: identification of the A genome donor species. Genome. 1993;36(1):21-31.

Genaev M.A., Komyshev E.G., Smirnov N.V., Kruchinina Y.V., Goncharov N.P., Afonnikov D.A. Morphometry of the wheat spike by analyzing 2D images. Agronomy. 2019;9(7):390. DOI 10.3390/agronomy 9070390.

Goncharov N.P. Genus Triticum L. taxonomy: the present and the future. Plant Syst. Evol. 2011;295:1-11.

Goncharov N.P., Bannikova S.V., Kawahara T. Wheat artificial amphiploids with Triticum timopheevii genome: preservation and reproduction of wheat artificial amphiploids. Genet. Resour. Crop Evol. 2007;54(7):1507-1514

Hammer K., Filatenko A.A., Pistrick K. Taxonomic remarks on Triticum L. and $\times$ Triticosecale Wittm. Genet. Resour. Crop Evol. 2011;58:3-10.
Holubec V., Leišová-Svobodová L., Matějovič M. Spontaneous hybridization within Aegilops collection and biobanking of crop wild relatives (CWR). Genet. Resour. Crop Evol. 2019;66(2):311-319.

Morrison L.A., Faberova I., Filatenko A.A., Hammer K., Knüpffer H., Margounov A., Rajaram S. Call to support an English translation of the 1979 Russian monograph of Triticum by Dorofeev et al. Wheat Inform. Serv. 2000;90:52-53.

Percival J. The Wheat Plant: A Monograph. London: Duckworth and Co., 1921.

Tsunewaki K. Plasmon analysis in the Triticum-Aegilops complex. Breed. Sci. 2009;59:455-470.

Tsunewaki K. Plasmon analysis in the Triticum-Aegilops complex (Erratum). Breed. Sci. 2010;60:177-178.

Vavilov N.I. The New Systematics of Cultivated Plants. In: The New Systematics. Oxford: Clarendon Press, 1940:549-566.

Конфликт интересов. Автор заявляет об отсутствии конфликта интересов.

Поступила в редакцию 18.02.2020. После рецензирования 10.03.2020. Принята к публикации 10.03.2020. 